\title{
Do corporate governance and ownership structure impact dividend policy in emerging markets during financial crises?
}

\author{
Medhi Mili $^{\mathrm{a}}$, Jean-Michel Sahut ${ }^{\mathrm{b}}$, Frédéric Teulon ${ }^{\mathrm{c}}$ \\ ${ }^{a}$ College of Business Administration, University of Bahrain (Bh) \\ ${ }^{\mathrm{b}}$ IDRAC Business School (Fr) \& HEG Fribourg (Ch) -- HES SO // University of Applied \\ Sciences Western Switzerland \\ ${ }^{\mathrm{c}}$ IPAG Business School (Fr)
}

\begin{abstract}
This paper analyzes governance and ownership structure and their impacts on dividend policy in emerging markets during financial crises. Our results provide strong evidence of the significant role of corporate ownership structure and board characteristics in explaining the behavior of dividend policy mainly during crisis periods. We show that firms with a higher proportion of institutional shareholders pursue higher dividend payout ratios. This study is of particular interest for business managers in their choice of strategies to be adopted in respect for dividend policy during crisis periods.
\end{abstract}

JEL classification: G35; G34.

Keywords: Corporate governance, Ownership structure, Dividend policy, Financial crisis. 


\section{Introduction}

Dividend policies in emerging countries remain underexplored. Glen, Miller and Shah (1995) and Mitton (2004), among others, find significant differences in dividend policies between firms operating in developed and developing countries. Adjaoud and Ben-Amar (2010) argue that emerging markets differ from developed markets in many aspects. Particularly, they suggest that emerging markets have specific corporate governance and ownership structure characteristics. They show that these two characteristics affect firms with dividend policies in developing countries. Mitton (2004) suggests that emerging markets provide low legal protection for investors and weak governance mechanisms compared to firms operating in developed countries. There are several fundamental differences between the ownership structures of companies in emerging and developed countries. In emerging economies, ownership structure is highly concentrated among institutional investors that hold the management of their firms, even when they become listed, while institutionals play an important role in decision making, regardless of their official status. The boards of these companies operate as an advisory committee rather than focusing on control. Due to these special ownership structures, expropriation of minority shareholders therefore appears more problematic in developing countries. The high ownership concentration and the particular corporate governance issue make emerging countries an interesting setting to investigate the dividend policy puzzle.

Another relevant issue related to dividend policy addressed by the literature is whether firms change their corporate dividend policy during financial crisis (Kowalewski, 2013). Hauser (2013) uses a life-cycle model to predict the probability that a firm pays dividends during the 2007-2009 period. He shows evidence that dividend payouts decline in crisis periods, even after taking the firm's financial condition into account. Bistrova et al. (2013) study the dividend policy of European companies during the financial crisis. Their results show that payout ratios declined slightly during the 2008-2009 financial crisis. The dividend payouts during the recession did not drop below the 50\% threshold, while in peak years, the share of dividend paying was approximately 57\%. Based on the agency theory, Abreu et al. (2013) suggest that the agency cost hypothesis explains dividend payouts before and during the financial crisis. However, the signaling hypothesis explains dividend payouts only during the financial crisis. The imbalance situations that arise from financial crises create power differentials between managers and shareholders. Managers seek to take advantage of these conditions by neutralizing the governance mechanisms and strengthening their discretion. The need for effective corporate governance mechanisms becomes more pronounced during troubled periods. Without effective protection of 
minority shareholders, high future earnings can increase outsiders' expropriation and, in turn, affect the firm's dividend payout.

The objective of this paper is to test the effect of corporate governance and ownership structure on the dividend payout policy in emerging markets. Furthermore, we test whether dividend policy shifts during the financial crisis period. Particularly, we focus on the impact of governance mechanisms on dividend policies in the Gulf Cooperation Council (GCC) and East Asian Countries. The GCC business environment has some attractive features that differ from that of East Asian countries. This makes the study, in terms of dividend policies in the GCC and East Asia countries, very relevant. First, the GCC countries have the particularity of dividends that are taxed very low (5\% in Saudi Arabia and 15\% in Kuwait) or are even non-taxable (Bahrain, UAE and Oman). This leads investors in these countries to prefer high-yield payouts. Second, stock markets in these countries are more volatile and entail a high degree of information asymmetry. Al-Kuwari (2009) suggests that agency costs are very high in these countries and that governance mechanisms are more developed than in other emerging countries.

This paper presents three main contributions to the existing reviews on dividend policy in emerging markets. First, our study provides updated research on the impact of corporate ownership structure and board governance on dividend policy in emerging countries. We use a sample of 362 non-financial firms spanning from 2003 to 2011. Our hypotheses are developed around variables that refer to agency cost and signal theories that have not previously been used in emerging countries. These considerations could provide additional insight into the dividend policy debate. Second, empirical studies focusing on the impact of CEO duality on the dividend policy were conducted on the developed countries and show inconclusive results. This makes the study of CEO duality in emerging markets appealing. Our research employs a specific approach to investigate the impact of CEO Duality on dividend policy in emerging countries. In a marked departure from other studies conducted in this regard, we investigate the differences between determinants of dividend policy on firms both with and without CEO Duality. Third, this research contributes to the understanding of dividend policy by testing whether the impact of corporate governance on dividend policy changes during crisis periods in emerging countries. While theoretical advancements in the field of governance practice undoubtedly allowed resolving several puzzles in corporate finance, there is no consensus on how dividend payouts are expected to change during the financial crisis. To the best of our knowledge, this work is the first to directly address this issue from this perspective. For this purpose, we interact the board governance variables with a dummy variable that captures the crisis effects. We assess that dividend payouts are of particular interest in unraveling the effect of external and internal corporate governance 
during crisis periods. This study is of particular interest to managers and shareholders when adjusting their dividend payout strategies during financial crises.

The remainder of the paper is structured as follows. Section 2 presents empirical literature related to dividend policy in emerging markets. Section 3 develops our hypothesis. Section 4 describes the data and reports summary statistics. The next section presents model specifications and variable definitions. Section 6 discusses the empirical results. The last section concludes the paper.

\section{Firm dividend policy in emerging countries during financial crises}

The empirical literature shows evidence that emerging markets differ from developed markets in many aspects. Recently, several researchers have focused particularly on the differences between dividend policies in both markets. Based on a sample of 19 emerging countries, Mitton (2004) claims that dividend policies exhibit specific characteristics that rely on the ownership structure and governance mechanisms that distinguish the emerging countries. He suggests that the level of economic development affects the degree of investor protection in the country. Most of his findings validate the agency theory arguments for the case of the emerging market. The agency theory states that outside stockholders have a preference for higher payouts to the detriment of reinvested earnings to limit the waste of internal funds by insiders. Developing countries provide lower investor protection, and the preference for dividends may be more relevant because outside shareholders perceive a higher risk of expropriation by insiders. Mitton's findings show a negative relationship between corporate governance and dividend payouts in countries with weak investor protection. Furthermore, he finds a strong negative relationship between dividend payouts and growth opportunities for well-governed firms. Amidu and Abor (2006) provide an insightful discussion on the determinants of dividend payout ratios in the emerging countries. They test the signal hypothesis, which establishes that, in emerging countries, managers have more information about the firm's future cash flows than outsiders. Managers have interest in signaling this information to the market (Gugler et al., 2003). Their results show significant positive relationships between the dividend payout ratio, profitability, cash flow, and tax. Therefore, risk and market-to-book value are shown to be negatively linked to dividend payouts. Omneya et al. (2010) use cross-sectional data on the top 50 listed Egyptian firms between 2003 and 2005 to examine the effect of board of directors' composition and ownership structure on dividend policies in Egypt. They find a significant positive relationship between institutional ownership and firm performance and between dividend policy and the payout ratio. Their results confirm that firms with higher financial profitability and higher institutional ownership paid higher dividends. 
However, they find that board composition has no significant effect on dividend decisions. Using a sample of GCC firms, Kuwari (2009) shows that dividend policy is significantly related to government ownership, firm size and firm profitability. His results show also a negative relationship between dividend payouts and the leverage ratio. He notes that, in the GCC region, firms pay dividends to resolve agency problems and to preserve firms' reputation.

Despite the importance of the empirical results highlighted above, no studies have tested the impact of board governance and ownership structure on dividend policy in emerging countries during the most recent crisis period (2007-2009). The recent financial crisis has generated several controversies about its origins, especially in terms of these origins as ways to overcome the crisis. Liberal economists have noted that this crisis reveals structural problems of the current economy, basically, the failure of corporate governance systems in both developing and developed countries. These problems are particularly severe in developing countries, where a lack of disclosure of information and proper audit accentuates minority shareholders' exposure to abuse by controlling owners. Moreover, in turbulent periods, it is difficult for firms to raise external funds mainly in emerging countries, where financial markets are not sufficiently liquid and yield spreads are very high. Thus, we expect that during crisis periods, firms in emerging markets should pay lower dividends.

Focusing on the Asian financial crisis, Sawaski (2009) tests the role of dividends in protecting shareholders' interests and how are they related to other governance practices. He reports that the Asian financial crisis stimulated substantial improvements in governance practices in all countries. His results show a significant positive relationship between quality of governance and dividend payouts during post-crisis periods in common law countries. The evidence that better-governed firms pay higher dividends implies that better governance reduces expropriation by insiders. This is perfectly feasible by acting on cash flow rights but not necessarily on control rights.

Based on this discussion, we claim that the special characteristics of ownership structure and corporate governance significantly affect dividend policy in emerging markets during periods of financial crisis.

\section{Hypothesis development}

This section develops our hypothesis on the impact of board governance and ownership structure on dividend policy. In particular, it focuses on how dividend policy in emerging markets is affected by financial crises. 


\subsection{Board Governance's impact on dividend policy in emerging countries}

Corporate boards play an important role in monitoring and controlling management. The quality of the Board's performance has been extensively examined through three fundamental characteristics (Jensen, 1983). First, the composition of the board, (i.e., the size of the board, the type of directors, and the existence of specialized committees) (Omneya et al., 2010; Schllenger et al., 1989); second, the board structure, which indicates the nature of management: monistic or dualistic (Gregory, 2000; Borokhovich et al., 2005; and Lipton and Larsh, 1992); and third, the intensity of the activity of the Board, which is generally measured by the frequency of its meetings (Conger et al., 1998; Schellenger, Wood and Tashakori, 1989; and Chen et al., 2011).

\section{Board size}

Great attention has been assigned to the Board size as a factor influencing the quality of management control. The analysis of previous studies shows divergent results about the influence of board size on dividend policy. In fact, there are two opposite results in the literature about the effect of board size. The first supports the idea that larger boards allow managers to specialize. Greater specialization can lead to more effective monitoring (Klein, 2002); for this reason, lower dividends are required for the monitoring role. In the same sense, the signal theory defends a large board size, which can be perceived as a good signal to the market; consequently, a high dividend payout is not required to reduce agency costs. The second defends that larger boards are less effective than the smaller boards owing to the quandaries of coordinating large groups (Jensen, 1993). Recently, Bokpin (2011) discussed the effect of ownership structure and corporate governance on dividend policy in the Ghana stock exchange during the 2002-2007 period. His findings illustrate a significant and positive relationship between board size and dividend policy. Boards' firms in emerging countries are very small in size. Therefore, smaller-sized boards result in lower agency costs to monitor managers. These costs can be even higher in times of crisis because managers tend to enjoy periods of turbulence to expropriate internal resources. Accordingly, Shareholders may require higher dividend payouts. Drawing on the above discussion, we expect that Board size should be positively related to dividend payouts in periods of crisis. The impact should be more important for East Asian countries where capital firms are more dispersed. We posit the following hypothesis.

$H_{1}$ : Board size positively affects dividend payouts in periods of crisis.

\section{The Board independence}

Board independence is considered a crucial characteristic of board structure. According to Gregory (2000), an independent director is an essential component of the internal control and the 
monitoring mechanism of the firm. An independent board director is intended to be a member of the audit, remuneration, and nomination committees. His role is important to ensure the integrity of financial statement disclosures and to guarantee appropriate internal controls in the company. Independent directors have an important role in monitoring and disciplining management because of their experience. Rozeff (1982) suggests that when management control mechanisms are weak, shareholders use dividend policy to monitor the management. Furthermore, independent nonexecutive directors may act as a monitoring device for the firm's management and, therefore, create a need for higher dividend payouts. If independent directors are an effective monitoring device, then board independence and dividend policy should be substitutes in the monitoring of agency problems. Borokhovich et al. (2005) examine the relationship between board independence and dividend policy over the 1992-1999 period for U.S. companies. Their results show a significant and negative relationship between board independence and dividend policy. Board independence strengthens the control power of shareholders, which reduces the use of dividend payouts. This is not the case for the emerging countries, where board independence is generally very low. Based on the previous discussion, we present our testable hypothesis as follows:

$\mathrm{H}_{2}$ : Board independence is associated with lower dividend payments.

\section{CEO Duality}

Duality is indicative of the power structure of the corporate board and is a basic variable of its efficiency. Jensen (1993) suggests that when the same person is the CEO and chairman of the board, the board of the directors cannot perform its key function. In this case, the internal control system will be very weak, and the CEO will get more power to control the board of directors. The independence of the board of directors is impacted. It will be more possible for the CEO to pursue his own interests but not all shareholders' interests. Baliga et al. (1996) suggest that in case of the CEO and chairman duality, the board is less effective in control mechanisms. This result is in line with the arguments of the agency theory, which states that duality promotes CEO entrenchment by reducing board monitoring effectiveness. Chen et al. (2005) examine the relationship between financial fundamentals, corporate governance and the propensity to pay cash dividends for Chinese listed companies. They show that Board size and the composition of senior management have a significant and positive impact on the likelihood of paying dividends. Furthermore, they show that the duality of CEOs' duty has a significant and negative impact on dividend payouts. In emerging countries, firms generally show CEO duality, which implies a high portion of insiders. This specific nature of board composition should have a negative effect on board 
performance, leading to an increase agency costs. As such, to better monitor managers and to limit their expropriation of cash flow, shareholders require higher dividend payouts.

From the above arguments, the following hypothesis is formed:

$H_{3}$ : There is a negative relationship between the CEO Duality and dividend policy.

\section{Board activity}

Regular meetings of the Board facilitate interaction between managers and directors and, therefore, enhance the vigilant monitoring function of the board. Indeed, increasing the frequency of meetings allows outside directors to have favored access to all information in the firm. Hence, regular meetings of the Board reduce agency cost and have a direct effect on the dividend policy (Lipton and Larsh, 1992). According to Conger et al. (1998), directors need sufficiently wellorganized periods of time to make effective decisions. Moreover, Laksmana (2008) supports the idea that a sufficient number of well-organized meetings could lead to board effectiveness. He shows that meeting frequency can be considered as a proxy for directors to perform their duties.

The literature exposed above shows that the board has a supervisory and advisory role (expert opinion) to ensure that managers defend the interests of shareholders (Jensen and Meckling, 1976). The frequency of board meetings measures the intensity and effectiveness of corporate monitoring and disciplining. This reduces the agency costs and limits the need for very high payouts. Therefore, we propose the following hypothesis:

$H_{4}$ : There is a negative relationship between the number of board meetings and dividend payouts. 


\subsection{Ownership structure's impact on dividend policy in emerging countries}

Ownership structure is a determinant factor of company policies. The importance of majority shareholders affects the decision-making power in their favor, such as dividends' decisions (Gugler, 2003; Kouki and Guizani, 2009). According to the agency theory, there are two basic compounds that enhance the efficiency of the ownership structure as an internal mechanism of corporate governance: the ownership concentration and the nature of the shareholders. In our research, we investigate the impact of these two elements on the firm's dividend policy.

\section{Ownership concentration: The monitoring hypothesis vs. the rent extraction hypothesis}

There are two competing views in the literature about the effect of ownership concentration on dividend payouts: the monitoring hypothesis and the rent extraction hypothesis.

The monitoring hypothesis states that the ownership concentration is associated with higher dividend payments. According to Shleifer and Vishny (1986), ownership concentration allows dominant shareholders to expropriate minority investors. This allows us to solve the free-rider problem related to dispersed ownership, where no single shareholder has enough incentives to incur monitoring costs for the benefit of all shareholders. Active monitoring promoted by majority shareholders makes business decisions in line with the interests of shareholders, which reduces agency costs and provides a good signal to the market about the control quality of the firm. Mitton (2004) explains that emerging market companies with high corporate governance indicators pursue a high dividend payment policy. As a matter of fact, payment indicators are higher when investment opportunities are low.

However, the rent extraction hypothesis recognizes that ownership concentration is associated with lower dividend payments. Most researchers who have tried to test this hypothesis were interested in the conflict between majority and minority shareholders. Shleifer and Vishny (1997) explain that large shareholders tend to gather benefits of control, which they do not have to share with minority shareholders. Johnson and al. (2000) describe many instances where controlling shareholders have expropriated minority shareholders of high-growth project opportunities. Claessens and Djankov (1999) and Maury and Pajuste (2002) show that ownership concentration reduces firm value, which decreases dividend payouts. These findings are in line with Faccio et al. (2001), who argue that the existence of a second large shareholder increases dividend payments. Gugler and Yurtoglu (2003) claim that the low dividend payout of majority-controlled firms in Germany is related to the probability that controlling shareholders extract private benefits at the expense of minority shareholders. They confirm that the rent extraction hypothesis also has implications for the levels of dividends paid. Interestingly, their results show that larger holdings 
of the largest owner reduce the dividend payout ratio, while larger holdings of the second largest shareholder increase it. Based on the previous discussion, we present our testable hypothesis as follows:

$H_{5}$ : Ownership concentration has a significant impact on dividend payments.

\section{Institutional Investors}

Institutional investors have a very influential role in corporate governance and are specifically concerned with reducing agency costs. Based on agency theory, several studies show that institutional investors significantly affect the dividend policy of their firms. Eckbo and Verma (1994) find that institutional investors would rather distribute free cash flow in the form of dividends over reinvesting them internally. Moreover, in their model, High dividend yield firms are associated with large institutional shareholders. Because this group of shareholders prefers high cash dividends, it is unlikely to participate in tax-induced trading over the ex-dividend day. Based on signal theory, Short et al. (2002) suggest that the presence of institutional shareholders may mitigate the use of dividends as a signal of good performance. Building on this hypothesis, several papers suggest that large institutional investors help to resolve agency problems by monitoring management (Waud, 1966; Fama and Babiak, 1968; Zeckhauser and Pound, 1990; Zhang and Keasey, 2002).

Contrarily, in emerging markets, institutional investors focus on governance as a way to enhance profitability markets, unlike in the developed countries, where institutional investors focus on governance as a way to avoid risk (Khanna and Zyla, 2010). Thus, we can expect that as the importance of the proportion of institutional investors increases, the dividend payouts in emerging markets will increase because cash dividends reduce the expropriation of managers of internal resources and increase the profitability of institutional shareholders. Based on the above discussion, we posit the following hypothesis.

$H_{6}$ : Institutional ownership affects dividend payments positively.

\section{Managerial ownership}

Jensen (1986) suggests that managers would rather preserve earnings instead of distributing them to shareholders to ensure the growth of the company and to maximize their personal benefits. Jensen et al. (1992) confirm that managerial ownership has a negative impact on dividend payout policy and firm debt. Building on these findings, Eckbo and Verma, (1994) show that dividends are a negative function of the increasing power of managerial ownership. Their results show that manager-controlled firms are associated with very low cash dividends because managers have absolute voting power. 
These studies have stimulated several follow-up studies that investigate the impact of managerial ownership on dividend policy. Focusing on Chinese firms, Chen et al., (2005) find a negative relationship between managerial ownership and dividend policy and show that managerial ownership is negatively associated with firm performance. Wen and Jia (2010) study the role of dividends in reducing agency costs by examining the relationship between dividends and managerial ownership, institutional ownership, and a set of other variables that measure the level of agency costs. They show that managerial ownership and institutional ownership are negatively associated with the dividend policy for bank holding companies. By examining the dividend policies of firms, Iranian, Mehrani, Moradi and Eskandar (2011) find opposite results. They show that there is no significant relationship between managerial ownership and dividend payouts.

In the absence of other governance mechanisms, dividend policy is likely to have an important role in monitoring management and reducing agency costs. This is the case of emerging markets characterized by high managerial ownership and low dispersed capital. We expect that dividend policies in emerging markets will be significantly affected by the managerial ownership of the firm. With reference to this literature review, we formulate the following alternative hypothesis:

$H_{7}$ : Managerial ownership is associated with lower dividend payments

\section{Model specifications and variable definitions}

Our empirical approach consists of a panel regression model to examine the relationship between board governance, ownership structure and dividend payouts. We first investigate the effect of board governance and ownership structure on dividend payout policy. Our common empirical model can therefore be stated as follows:

$$
D P_{i t}=\beta_{0}+\sum_{k} \beta_{k} \text { Own_ } S_{i t}+\sum_{l} \beta_{l} \text { Board_G }_{i t}+\sum_{h} \beta_{h} \text { Control }_{i t}+\varepsilon_{i t} \quad \text { (Model 1) }
$$

Where:

$D P_{i t}$ is the dependent variable that defines the dividend policy of firm $i$. We use two dependent variables separately. The dividend payout is measured by the dividend yield (D_Yield) and dividend decision $\boldsymbol{D}_{-}$Dec , which is a dummy variable that equals one if the firm decides to pay dividends and zero otherwise.

Own_S $S_{i t}$ denotes ownership structure variables. Four measures of ownership structure are used in this analysis. Inst_Own is institutional ownership, and it is measured as the percentage of shares held by institutions. Mang_Own is Managerial ownership, and it is defined as the proportion of equity capital owned by managers and directors. Conc is Ownership concentration. Top5_Share is the sum of shares owned by the largest five shareholders.

Board_G $G_{i t}$ denotes board governance variables. Four measures of board governance are used in this analysis. These are board independence, board size, CEO duality, and intensity. Board_indep is board independence, and it is defined as the number of independent board members on the corporate board. Board_size is board size, and it is defined as the number of board members. Int is board intensity, and it is defined as the number of board meetings per year. Duality is a dummy that takes a value of one if the CEO is also the board chairman and zero otherwise. 
Control $_{i t}$ are control variables. Eight Control variables are used in this paper: Firm age, Beta, Firm size, ROE, effective tax rate, debt and invested capital. To control for the Industry sector, we add a dummy variable that takes the value of 0 for a non-financial company, 1 for a petroleum company, 2 for a financial company and 3 for a service company.

Table 1 provides the definitions of all the variables used in our analysis.

Table 1 - Definition of variables

\begin{tabular}{|c|c|}
\hline Variable & Description \\
\hline \multicolumn{2}{|c|}{ Dependent Variables } \\
\hline D_Yield & Dividend yield (Annual Dividend Per Share as a Percentage of the Share Price) \\
\hline D_Dec & $\begin{array}{l}\text { Dividend decision (Dummy variable; equals one if the firm decides to pay dividends, zero } \\
\text { otherwise) }\end{array}$ \\
\hline \multicolumn{2}{|c|}{ Independent Variables } \\
\hline \multicolumn{2}{|c|}{ Ownership variables } \\
\hline Inst_Own & Institutional Ownership (The percentage of a firm's shares held by institutions) \\
\hline Conc & $\begin{array}{l}\text { Ownership concentration (Dummy variable; equal one if the percentage of shares owned by } \\
\text { largest shareholder are over } 50 \% \text {, zero otherwise) }\end{array}$ \\
\hline Top5_Share & Top 5 shareholders (the sum of shares owned by the largest five shareholders) \\
\hline Mang_Own & Managerial Ownership (The percentage of a firm's shares held by managers) \\
\hline \multicolumn{2}{|c|}{ Board variables } \\
\hline Int & Intensity (the number of board meetings) \\
\hline Board_size & Board size (the number of board members) \\
\hline Duality & CEO Duality (a dummy equal to one if the CEO is also the board chair and zero otherwise) \\
\hline Board_indep & Board independence (The number of independent board members on the corporate board) \\
\hline \multicolumn{2}{|c|}{ Control variables } \\
\hline Firm_age & $\begin{array}{l}\text { Listing age in this study employed the age of the listing (AGE) as a proxy for firm age rather } \\
\text { than the year of incorporation to control for firm maturity) }\end{array}$ \\
\hline Beta & Beta, systematic risk \\
\hline Firm size & The natural logarithm of total market capitalization \\
\hline ROE & Return on equity (Net Income divided by Average Total Equity) \\
\hline Tax & Effective Tax rate \\
\hline Debt & Total Debt \\
\hline Industry & $\begin{array}{l}\text { Dummy variable ( } 0 \text { Industrial company, } 1 \text { petroleum company, } 2 \text { financial company and } 3 \\
\text { service company) }\end{array}$ \\
\hline
\end{tabular}

\section{Data collection, descriptive statistics and preliminary analyses}

This section presents the data used in our study and describes summary statistics. We also present univariate and bivariate analysis to provide an overview of the characteristics of our sample.

\subsection{Sample and data collection}

Our sample consists of 362 listed firms and covers the 2003-2011 period; 187 of the selected firms come from four East Asian countries - Malaysia, Thailand, Taiwan, Indonesia - and 175 from four GCC countries - Bahrain, Saudi Arabia, Kuwait and Oman. For conformity with previous studies, financial institutions are excluded from our sample due to their specific financial 
characteristics (i.e., Banks, securities firms and insurance companies). We collected data from the Worldscope database and corporate governance statistics from firms' annual reports.

Though it began with more than 500 companies, the sample was later substantially reduced because we exclude the companies with missing performance or control variables. The final data set for the panel regressions consists of 362 listed companies.

In developing countries, small and medium-sized firms are highly concentrated; to ensure that this effect will have no impact on our results, we select firms with large sizes.

\subsection{Descriptive Statistics and preliminary analysis}

This section provides summary statistics and the correlation coefficients of the variables used in the analysis. Table 2 reports the mean and standard deviation of all the variables used in the study, as well as percentile statistics. Overall, the dividend decision registers a mean of 0.531 , which denotes that more than 53\% of the firms have paid dividends over 2003-2011. The Dividend yield has an average value of 5.23\%. This value is slightly higher than that reported by Omneya et al. (2010), who document a dividend yield mean of 4.34\% on the Egyptian market. Dividend yield and dividend decisions of GCC banks appear higher overall than those of East Asian banks.

Our preliminary statistics show that duality is a distinctive feature of firms from emerging countries, which is again confirmed by our results. The table shows that $51.37 \%$ of companies operate with CEO-chairman duality. This is consistent with the results of Wellalage and Locke (2011) and Alsayed (2007), who find high duality in emerging countries. However, this percentage is higher than those reported by Kim et al. (2010) and Faleye (2007) in the developed countries. CEO-Chairman duality appears more common in East Asian countries (69.8\%) than in GCC countries (38.7\%).

Table 2 also shows that more than one-third of firms in our sample have concentrated ownership structures. On average, the concentration ownership of the whole sample is $32.37 \%$. East Asian firms appear more concentrated than GCC firms. Additionally, our sample includes both small and large firms (with a mean and standard deviation for Firm_size of 7.239 and 3.329, respectively) and low- and high-profit firms (with a mean and standard deviation for ROE of 0.189 and 0.391 , respectively). 
Table 2: Summary statistics

This table provides descriptive statistics of all variables used in the paper. The sample contains 362 non-financial firms over the 2003-2011 period. Definitions of all variables are reported in table 1.

All Firms East Asian Firms

GCC Firms

\begin{tabular}{lllllll}
\hline Variables & Mean & Std. Dev. & Mean & Std. Dev. & Mean & Std. Dev. \\
\hline & & & & & & \\
D_Yield & 0.05239 & 0.05612 & 0.04529 & 0.02612 & 0.06724 & 0.03871 \\
D_Dec & 0.57122 & 0.79921 & 0.58117 & 0.34219 & 0.74923 & 0.56523 \\
Duality & 0.51339 & 0.69395 & 0.69853 & 0.63704 & 0.3861 & 0.32908 \\
Int & 7.25732 & 3.23717 & 7.90318 & 2.21453 & 6.21988 & 1.98545 \\
Board_size & 5.31729 & 3.68239 & 6.81541 & 2.42198 & 4.21953 & 1.04781 \\
Board_indep & 4.71933 & 1.33923 & 3.57126 & 1.25731 & 5.32721 & 2.89176 \\
Inst_Own & 0.24332 & 0.1391 & 0.18932 & 0.12632 & 0.39416 & 0.19753 \\
Mang_Own & 0.33017 & 0.33203 & 0.42669 & 0.24325 & 0.20931 & 0.12934 \\
Conc & 0.32369 & 0.32217 & 0.48214 & 0.19841 & 0.21456 & 0.47611 \\
TOP5_Shar & 0.38129 & 0.1229 & 0.49825 & 0.11385 & 0.27543 & 0.08763 \\
Firm_age & 13.7013 & 9.23929 & 14.1451 & 8.47833 & 11.5329 & 7.21842 \\
Beta & 0.73212 & 0.23019 & 0.65933 & 0.22343 & 0.94276 & 0.45871 \\
Firm_size & 7.2393 & 3.32933 & 9.23442 & 2.47831 & 4.92933 & 1.62109 \\
ROC & 0.15402 & 0.7291 & 0.16248 & 0.92011 & 0.12425 & 0.50883 \\
ROE & 0.18934 & 0.39127 & 0.12564 & 0.23956 & 0.19404 & 0.43216 \\
Tax & 0.12681 & 0.19293 & 0.1974 & 0.12718 & 0.34821 & 0.26453 \\
Debt & 1709.28 & 1230.32 & 2041.37 & 1294.29 & 1540.42 & 982.05 \\
Invested_capital & 692.237 & 358.058 & 791.195 & 459.923 & 539.266 & 293.347 \\
\hline
\end{tabular}

Table 3 reports the Pearson correlation coefficients between the main variables used in the study, as well as their degrees of significance. Bryman and Cramer (1997) suggest that the coefficient of Pearson correlations between the independent variables must not exceed 0.80 ; otherwise, a coefficient greater than 0.80 may reveal multicollinearity.

Several interesting relations can be highlighted. First, the correlation coefficients between D_Yield and D_Dec are positive and statistically significant at the 5\% level. Second, all board

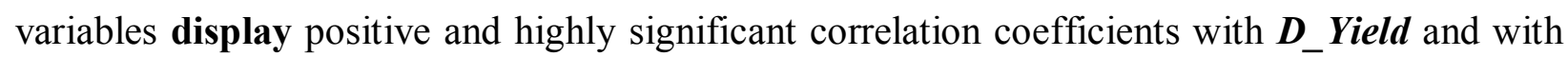
D_Dec. Third, all ownership variables except TOP5_Shar and Mang_Own are significantly correlated with D_Yield. On the whole, these findings lend preliminary support to our theoretical predictions. Contrary to size and Profitability variables (ROC and ROE), which appear to be positively correlated with $\boldsymbol{D}_{-}$Yield and $\boldsymbol{D} \_\boldsymbol{D e c}$, the debt variable appears to be negatively and significantly correlated with dividend payouts. 
To test the fixed effect in our econometric specification, we run the Hausman test. The null hypothesis shows that the preferred model has random effects vs. alternative fixed effects. The results of the regression show that the $\mathrm{p}$-value of the $\mathrm{F}$ statistic is equal to 0.003 . As a result, the random estimation method is rejected. The P-value of Hausman statistics show that the fixed effects method should be used to estimate our specifications.

We suspect endogeneity problems in our estimates relating to causality between exogenous variables and the dependent variables (especially the debt variable). Therefore, traditional econometric methods (OLS and fixed effects generalized least squares) do not enable us to obtain efficient estimates of this model. To solve this problem, we use the generalized method of moments (GMM) to estimate our panel models.

Moreover, using this method (GMM) to estimate panel models has another advantage. It generates instruments from the explanatory variables, which is not the case for other traditional methods such as instrumental variables (2SLS and 3SLS), which require the selection of theoretical instrumental variables correlated and uncorrelated with the explanatory variables.

\section{Empirical results}

To test the fixed effect in our econometric specification, we run the Hausman test. The null hypothesis states that the entity-specific errors are not correlated with independent variables. The results of the regression show that the P-value of the F-statistic is equal to 0.000 . As a result, the compilation data estimation method (common effect method) is rejected. Therefore, the Hausman test is performed to select the appropriate method of estimation. The P-value of Hausman statistics also demonstrates that the fixed effects method is more appropriate for our model. 


\section{Table 3: Correlation matrix}

This table reports the correlation between variables used in this paper. The sample contains 362 non-financial firms over the $2003-2011$ period. Definitions of all variables are reported in table 1 . *significant at the 5 percent level of significance.

D_Yield D_eic Duality Int $\quad$ Board_size Board_indep Inst_Own Mang_Own $\quad$ Conc $\quad$ TOP5_shar $\quad$ Firm_age Beta Firm_size ROC ROE Tax Debt Invested_capital

\begin{tabular}{|c|c|c|c|c|c|c|c|c|c|c|c|c|c|c|c|c|c|c|}
\hline D_Yield & 1.0000 & & & & & & & & & & & & & & & & & \\
\hline D_Dec & $0.4332 *$ & 1.0000 & & & & & & & & & & & & & & & & \\
\hline Duality & $0.3999 *$ & $0.3449^{*}$ & 1.0000 & & & & & & & & & & & & & & & \\
\hline Int & $0.1989 *$ & $0.3499^{*}$ & $0.0389^{*}$ & 1.0000 & & & & & & & & & & & & & & \\
\hline Board_size & $0.3422^{*}$ & $0.2999^{*}$ & $0.4904^{*}$ & $0.5210^{*}$ & 1.0000 & & & & & & & & & & & & & \\
\hline Board_indep & $0.2890^{*}$ & $0.1792^{*}$ & $0.5033^{*}$ & $0.9992^{*}$ & $0.4781^{*}$ & 1.0000 & & & & & & & & & & & & \\
\hline Inst_Own & $0.2509^{*}$ & $0.0893^{*}$ & -0.0843 & 0.0944 & $0.0298^{*}$ & $0.3093^{*}$ & 1.0000 & & & & & & & & & & & \\
\hline Mang_Own & -0.0449 & -0.0639 & 0.0342 & $-0.9420^{*}$ & $-0.1442^{*}$ & $-0.2942^{*}$ & -0.0441 & 1.0000 & & & & & & & & & & \\
\hline Conc & $0.0379^{*}$ & $0.0409^{*}$ & $0.0499^{*}$ & -0.0394 & $0.1360^{*}$ & $0.0944^{*}$ & $-0.9429^{*}$ & $-0.9443^{*}$ & 1.0000 & & & & & & & & & \\
\hline TOP5_Shar & 0.0242 & 0.0994* & $0.0299^{*}$ & $0.0890^{*}$ & $0.1809^{*}$ & 0.0994 & $-0.4933^{*}$ & $-0.9988^{*}$ & $0.2949^{*}$ & 1.0000 & & & & & & & & \\
\hline Firm_age & 0.0324 & $0.2094^{*}$ & $0.9904^{*}$ & -0.0399 & -0.0398 & -0.0939 & 0.0049 & $-0.0428^{*}$ & $0.1939^{*}$ & 0.1589 & 1.0000 & & & & & & & \\
\hline Beta & $-0.2409^{*}$ & $-0.1498^{*}$ & $-0.3949^{*}$ & 0.0209 & -0.0099 & $0.5214^{*}$ & 0.0829 & 0.0034 & -0.0280 & $-0.0999^{*}$ & -0.0939 & 1.0000 & & & & & & \\
\hline Firm_size & 0.0094 & 0.0304 & -0.0922 & $0.0579^{*}$ & $0.3398 *$ & $0.9942^{*}$ & $0.0493^{*}$ & $-0.2820^{*}$ & $0.1803^{*}$ & $0.1248^{*}$ & -0.0043 & $0.3089^{*}$ & 1.0000 & & & & & \\
\hline ROC & 0.9949* & $0.5099^{*}$ & 0.0240 & 0.0298 & 0.0230 & 0.2839 & 0.0989 & 0.0594* & $0.0438^{*}$ & -0.0929 & 0.04658 & 0.0994 & $0.1153^{*}$ & 1.0000 & & & & \\
\hline ROE & $0.9288^{*}$ & $0.3920^{*}$ & $0.0198 *$ & $0.2035^{*}$ & $0.0209^{*}$ & 0.0342 & $0.0999 *$ & $0.0489^{*}$ & $0.0440^{*}$ & -0.0309 & $-0.0499^{*}$ & 0.04813 & $0.9839^{*}$ & $0.3920^{*}$ & 1.0000 & & & \\
\hline Tax & $0.0842 *$ & $0.2640^{*}$ & $0.0894 *$ & 0.0248 & $0.0849^{*}$ & 0.0334 & 0.0308 & 0.5639 & 0.0030 & -0.0040 & $0.0499^{*}$ & 0.00799 & 0.0294 & $0.0990^{*}$ & $0.9039^{*}$ & 1.0000 & & \\
\hline Debt & $-0.0442^{*}$ & $-0.0994^{*}$ & $-0.0490^{*}$ & -0.0209 & $-0.0226^{*}$ & $0.0484^{*}$ & 0.0944 & $0.3709^{*}$ & $0.0449^{*}$ & 0.0904 & 0.0289 & -0.0023 & $0.0982^{*}$ & 0.13829 & -0.0993 & -0.0999 & 1.0000 & \\
\hline Invested_capital & $0.0473 *$ & 0.0928 & -0.0048 & $0.0498^{*}$ & $0.0249^{*}$ & $0.133^{*}$ & $0.4794 *$ & $0.3843^{*}$ & $0.0359^{*}$ & $0.5434 *$ & 0.0839 & 0.0279 & $0.2094^{*}$ & -0.0998 & 0.0940 & -0.0003 & $0.5399 *$ & 1.0000 \\
\hline
\end{tabular}




\section{Impact of ownership structure on dividend policy}

Table 4 reports the GMM fixed effects panel estimation results of model 1. As expected, institutional ownership has a positive and significant effect on firms' dividend policies and firms' dividend payouts in both regions. This finding confirms that the market did not interpret the presence of an institutional shareholder as signaling good news regarding the firm's management efficiency. Han et al. (1999) find the same result and suggest that the positive relationship between dividend payouts and institutional ownership supports the tax-based hypothesis. Their finding conjectures a certain type of "dividend clientele," that is, institutions" preference for dividends. However, this result is contradictory to the findings of Short et al. (2002), who claim that large institutional ownership may mitigate the use of dividends as a signal of good performance.

Ownership concentration appears to be significantly and negatively related to firms' dividend payouts in both regions. In line with Harada and Nguyen (2005), we suggest that ownership concentration plays a significant role in corporate decisions on dividend payout policy in emerging countries. This result is contrary to that found for developed countries by Zeckhauser and Pound (1990), who did not find a significant relationship between dividend payout ratios and large block holders. They conclude that ownership concentration and dividend policy cannot be considered as substitute monitoring devices. The concentration of ownership has a significant impact on the dividend decision in the GCC countries and does not affect the dividend decision in East Asian Countries.

CEO duality is found to have a significantly positive effect on dividend policy and dividend payouts in both regions. This result disproves our initial hypothesis. This means that firms with CEOs and chairman positions held by the same person tend to pursue a high dividend payout policy. This result can be explained by the fact that combining the chairman and CEO positions in emerging markets cannot be considered as an effective tool to mitigate expropriation risk. Therefore, to resolve free cash flow problems, shareholders require higher dividend payouts. This argument corroborates findings by Baliga et al. (1996), who argue that CEO duality is not an effective control mechanism in developed countries.

The table also shows a positive and significant relationship between board size and firms' dividend payouts in East Asian countries. Contrary to the findings of Omneya et al.(2010), we suggest that larger board size is associated with high dividend payouts. The numerical increase of board size reduces agency costs for monitoring managers and can be perceived by the market as a positive signal that affects firms' dividend decisions. La Porta et al. (2000) suggest that large 
boards provide higher protection of shareholders' interests and increase dividend payouts. Contrarily, the Board size has no significant effect on dividend decisions.

The board independence variable appears to have a significant and negative effect on dividend payouts and the dividend decision. This impact is more significant for firms in the GCC countries. This indicates that firms with a higher percentage of external board members may pursue low-dividend payout policies. Our estimation also shows a significant positive relationship between board intensity and dividend payouts. Thus, we can deduce that a very active board has the potential to help align the incentives of managers and shareholders through its impact on the payout policy.

Among control variables, Beta and total debt have a significant negative effect on dividend decisions and dividend payouts. Firm age is found to be positively significant for dividend decisions, especially for East Asian countries. This result corroborates previous studies (AlMalkawi, 2007) that suggest that mature firms do not have a great interest in future investment growth, which allows shareholders to require dividend payouts. Another possible explanation is that large firms have higher agency costs due to the dispersion of their ownership, which requires additional monitoring and control, and higher dividends provide this complementary governance role.

The tax rate has a negative and significant effect on dividend yield in East Asian countries but no significant impact on firms' dividend yield in GCC Countries. This shows that higher tax rates in East Asian countries reduce dividend policy and that Board members favor reinvesting incomes if equity returns are sufficiently competitive. ROE appears insignificant for GCC and East Asian countries, confirming the dividend irrelevance theory of Miller and Modigliani (1961). The dividend irrelevance theory states that shareholders and stockholders remain constant in perfect market conditions and that any growth in the current payout is financed by literally priced stock sales ${ }^{1}$.

\footnotetext{
${ }^{1}$ To test the impact of the Return on assets on dividend payouts, we re-run our model by replacing the ROE with ROA. The results also show a non-significant coefficient of ROA, once again confirming the dividend irrelevance theory.
} 
Table 4. Regression results of the impact of corporate governance and ownership structure on dividend policy

This table reports the GMM fixed effects panel model estimation. The model sets the relationship between board governance and dividend policy for a sample of 362 non-financial firms over the 2003-2011 period. Dependent variables are Dividend decision (D_Dec) and dividend yield D Yield), respectively. Definitions of all variables are reported in table1. $\bar{t}$-statistics are reported in parentheses. $* * *, * * *$ indicate significance at the 1,5 and 10 percent levels of significance, respectively

\begin{tabular}{|c|c|c|c|c|}
\hline & \multicolumn{2}{|c|}{ D_Dec } & \multicolumn{2}{|c|}{ D_Yield } \\
\hline & East Asian & $\mathrm{GCC}$ & East Asian & $\mathrm{GCC}$ \\
\hline & Countries & Countries & countries & Countries \\
\hline \multirow[t]{2}{*}{ Inst_Own } & $0.4718 * * *$ & $0.3694 * * *$ & $0.0187 * * *$ & $0.2917 * * *$ \\
\hline & (4.729) & (4.531) & (4.079) & (4.784) \\
\hline \multirow[t]{2}{*}{ Conc } & -0.0584 & $-0.1378 * *$ & $-0.3472 * * *$ & $-0.0846 * * *$ \\
\hline & $(0.391)$ & $(2.070)$ & $(3.185)$ & $(6.141)$ \\
\hline \multirow[t]{2}{*}{ TOP5_Shar } & 0.0284 & -0.7231 & -0.0375 & $-0.7923 * * *$ \\
\hline & $(0.71)$ & $(-1.07)$ & $(-1.71)$ & $(-7.474)$ \\
\hline \multirow[t]{2}{*}{ Mang_Own } & -0.1847 & 0.0627 & 0.0391 & -0.0864 \\
\hline & $(0.002)$ & $(0.302)$ & $(0.004)$ & $(-0.132)$ \\
\hline \multirow[t]{2}{*}{ Duality } & $0.3468 * * *$ & $0.5713 * * *$ & $0.2876 * * *$ & $0.4981 * * *$ \\
\hline & (3.751) & $(9.563)$ & (2.179) & (3.591) \\
\hline \multirow[t]{2}{*}{ Int } & 0.9712 & 1.4316 & $0.0236^{* *}$ & 0.3417 * \\
\hline & $(0.683)$ & $(0.092)$ & (2.041) & (1.784) \\
\hline \multirow[t]{2}{*}{ Board_size } & 0.0392 & 0.0438 & $0.0953 * * *$ & 0.2951 \\
\hline & $(0.001)$ & $(0.105)$ & (3.027) & $(0.201)$ \\
\hline \multirow[t]{2}{*}{ Board_indep } & $-0.2356 * * *$ & $-1.7428 * * *$ & $-0.3368 * * *$ & $-0.9412 * * *$ \\
\hline & $(-3.237)$ & $(-6.351)$ & $(-2.978)$ & $(-4.801)$ \\
\hline \multirow[t]{2}{*}{ firm_age } & $0.0574 * * *$ & $0.7471 *$ & $0.5282 *$ & 1.8247 \\
\hline & (4.351) & (1.842) & (1.812) & (1.134) \\
\hline \multirow[t]{2}{*}{ Beta } & $-0.1892 * * *$ & $-0.1624 * * *$ & $-0.0875 * *$ & $-0.5981 * * *$ \\
\hline & $(-2.284)$ & $(-7.248)$ & $(-2.287)$ & $(-4.876)$ \\
\hline \multirow[t]{2}{*}{ Firm_size } & $0.0735 * * *$ & $0.2872 *$ & -0.1874 & -0.0372 \\
\hline & (7.189) & (1.734) & $(-1.184)$ & $(-1.047)$ \\
\hline \multirow[t]{2}{*}{ ROE } & -0.0364 & -0.0148 & -0.0374 & -0.0075 \\
\hline & $(-0.427)$ & $(-0.781)$ & $(-0.197)$ & $(-0.145)$ \\
\hline \multirow[t]{2}{*}{ Tax } & -0.3143 & -0.0472 & $-0.2843 * *$ & 0.0542 \\
\hline & $(0.284)$ & $(0.001)$ & (2.471) & $(0.481)$ \\
\hline \multirow[t]{2}{*}{ Debt } & $-0.0423^{*}$ & $-0.0348 * *$ & $-0.0941 * * *$ & $-0.3971 * *$ \\
\hline & (1.874) & $(-2.394)$ & (3.048) & (1.995) \\
\hline \multirow[t]{2}{*}{ Industry } & -0.0054 & -0.0071 & 0.0002 & 1.0001 \\
\hline & $(-0.442)$ & $(-0.753)$ & $(0.794)$ & $(0.280)$ \\
\hline \multirow[t]{2}{*}{ Constant } & $-0.2164 * * *$ & $-0.7143 * * *$ & $-0.2942 * * *$ & $0.8651 * * *$ \\
\hline & $(-7.961)$ & $(-4.037)$ & $(-6.167)$ & $(2.191)$ \\
\hline R-squared & 0.4821 & 0.5413 & 0.3691 & 0.3820 \\
\hline Wald-Test & $135.76^{* * *}$ & $158.45^{* * *}$ & $231.93 * * *$ & $187.23 * * *$ \\
\hline Obs. & 1754 & 1521 & 1754 & 1521 \\
\hline
\end{tabular}

\section{The effect of CEO Duality on dividend policy}


CEO duality has attracted particular attention in the literature on dividend policy. However, Empirical work has not brought conclusive evidence regarding the effect of CEO duality on dividend payouts (Baliga et al., 1996 and Chen et al., 2011). In this section, we study in greater depth the impact of CEO duality on policy. For this purpose, we split our sample into two groups. The first group includes firms with CEO duality, and the second includes firms without CEO duality. We therefore estimate the same model (1) separately for those two groups of firms. To account for the region effect in our sample, we add a dummy variable (Region) that takes a value of 1 if the firm is a member of the GCCs and 0 if it is a member of East Asian countries. The estimation results are reported in table 5. Panel A and Panel B estimate the model with the dividend yield and dividend decision as dependent variables, respectively.

A comprehensive result that can be mentioned is that, in emerging countries, dividend policy in firms with and without CEO duality does not depend on the same set of factors. Particularly, differences occur between ownership concentration and Top5_Shar variables. Thus, we find that, for firms with CEO duality, the dividend policy is significantly and negatively related to Top5_Shar and Concentration variables. This result may have a specific explanation for emerging countries. Large shareholders in the emerging markets seek to gather the earnings of their control that do not want to share with minority shareholders, so they can have a higher impact on firms' dividend decision for firms operating with CEO duality.

The impact of capital concentration on dividend yields appears similar in East Asian and GCC countries, but the impact is larger in size for GCC firms with CEO-chairman duality. The negative impact of capital concentration also appears more significant for GCC firms operating with CEO duality. The top 5 shareholders' coefficient is significantly positive only for the dividend yield of GCC firms with CEO duality. Its impact on East Asian firms is non-significant.

We also notice a significant negative relationship between board independence and dividend payouts for firms with CEO duality. This indicates that these firms with high percentage of external board members pursue a low dividend policy. Board independence plays an important role in the developing countries; we suggest that in firms with CEO Duality, independents have a stronger impact on dividend policy and prefer to reinvest earnings rather than paying dividends. This confirms some of the Findings of Omneya et al. (2010), who argue that the Board's independence must reach a certain threshold to be effectively decisive. The impact of board independence is more significant for the dividend yield of East Asian firms with CEO duality. 
This variable has no significant impact for firms without CEO duality in both regions. The impact of board independence on dividend decisions is similar in size for firms in both regions.

Table 5. Regression results of the effect of CEO Duality on dividend policy

This table reports the GMM fixed effects panel model estimation. The model sets the relationship between board governance and dividend policy for a sample of 362 non-financial firms over the 2003-2011 period. We split our sample into two groups. The first group includes firms with CEO duality, and the second includes firms without CEO duality. We therefore estimate the same model (1) separately for those two groups of firms. The dependent variable in Panel A is dividend yield (D_Yield), and that in Panel B is Dividend decision (D_Dec). Definitions of all variables are reported in table 1. t-statistics are reported in parentheses. $* * * * *, *$ indicate significance at the 1,5 and 10 percent levels of significance, respectively.

Panel A. Impact on Dividend Yield

\begin{tabular}{|c|c|c|}
\hline & \multicolumn{2}{|c|}{ All Firms } \\
\hline & $\begin{array}{c}\text { CEO } \\
\text { Duality }=0 \\
\end{array}$ & $\begin{array}{c}\text { CEO } \\
\text { Duality }=1\end{array}$ \\
\hline Inst_Own & $\begin{array}{r}0.8053 * * \\
(2.511)\end{array}$ & $\begin{array}{r}0.9612 * * \\
(2.542)\end{array}$ \\
\hline Conc & $\begin{array}{l}-0.0462 \\
(0.002)\end{array}$ & $\begin{array}{r}0.3955 * \\
(1.699)\end{array}$ \\
\hline TOP5.Shar & $\begin{array}{l}0.0382 \\
(0.000)\end{array}$ & $\begin{array}{l}-0.7259 \\
(-1.625)\end{array}$ \\
\hline Mang_Own & $\begin{array}{r}-0.0191552 \\
(-1.029)\end{array}$ & $\begin{array}{l}0.0524 \\
(1.370)\end{array}$ \\
\hline Int & $\begin{array}{r}0.3605 * * * \\
(2.395)\end{array}$ & $\begin{array}{r}0.04423 \\
(0.012)\end{array}$ \\
\hline Board_size & $\begin{array}{r}0.2523 * * * \\
(0.215)\end{array}$ & $\begin{array}{r}0.3672 * * * \\
(5.327)\end{array}$ \\
\hline Board_indep & $\begin{array}{l}-0.0084 \\
(-1.530)\end{array}$ & $\begin{array}{r}-0.0325 * * \\
(-2.031)\end{array}$ \\
\hline firm_age & $\begin{array}{r}0.00643 \\
(0.853)\end{array}$ & $\begin{array}{l}0.0086 \\
(1.262)\end{array}$ \\
\hline Beta & $\begin{array}{l}-0.0081 \\
(-0.099)\end{array}$ & $\begin{array}{l}-0.0051 \\
(-1.056)\end{array}$ \\
\hline Firm_size & $\begin{array}{l}-0.0035 \\
(-0.592)\end{array}$ & $\begin{array}{r}-0.072 * * * \\
(-2.585)\end{array}$ \\
\hline ROE & $\begin{array}{l}-0.0235 \\
(-0.120)\end{array}$ & $\begin{array}{l}0.0735 \\
(0.013)\end{array}$ \\
\hline Tax & $\begin{array}{l}0.0073 \\
(0.090)\end{array}$ & $\begin{array}{l}-0.0461 \\
(-0.005)\end{array}$ \\
\hline Debt & $\begin{array}{l}-0.0007 \\
(-0.181)\end{array}$ & $\begin{array}{l}-0.0008 \\
(-1.025)\end{array}$ \\
\hline Industry & $\begin{array}{l}0.0012 \\
(0.062)\end{array}$ & $\begin{array}{r}0.0041 \\
(-0.023)\end{array}$ \\
\hline Region & $\begin{array}{r}0.4885 * \\
(1.821)\end{array}$ & $\begin{array}{r}0.0722 * * \\
(1.995)\end{array}$ \\
\hline
\end{tabular}

\begin{tabular}{rr}
\hline \multicolumn{2}{c}{ East Asian Firms } \\
\hline CEO & \multicolumn{1}{c}{ CEO } \\
Duality $=\mathbf{0}$ & Duality $=\mathbf{1}$ \\
\hline $\mathbf{0 . 1 0 4 6}$ & $\mathbf{0 . 6 2 5 1 * * *}$ \\
$\mathbf{( 0 . 0 1 1 )}$ & $\mathbf{( 3 . 4 9 7 )}$ \\
0.0284 & $\mathbf{0 . 2 2 3 0 * * *}$ \\
$(0.014)$ & $\mathbf{( 2 . 6 9 6 )}$ \\
0.0612 & -0.2149 \\
$(0.000)$ & $(0.899)$ \\
-0.0128 & 0.0428 \\
$(0.425)$ & $(1.655)$ \\
$\mathbf{0 . 6 9 0 4 * * *}$ & $0.3278 * * *$ \\
$(\mathbf{2 . 6 9 4 )}$ & $(3.534)$ \\
$\mathbf{0 . 3 4 2 6 * * *}$ & $\mathbf{0 . 6 1 8 3 * * *}$ \\
$\mathbf{( 5 . 2 1 4 )}$ & $\mathbf{( 4 . 6 1 1 )}$ \\
-0.0267 & $\mathbf{- 0 . 1 3 2 4 * * *}$ \\
$(1.468)$ & $\mathbf{( 2 . 8 3 0 )}$ \\
0.0035 & 0.0193 \\
$(0.146)$ & $(0.283)$ \\
-0.0387 & -0.1543 \\
$(0.038)$ & $(0.002)$ \\
-0.0064 & $\mathbf{- 0 . 0 1 8 5 * *}$ \\
$(0.483)$ & $\mathbf{( 2 . 4 1 4 )}$ \\
-0.0264 & 0.0484 \\
$(-0.120)$ & $(0.072)$ \\
0.0076 & -0.0481 \\
$(0.090)$ & $(0.004)$ \\
-0.0014 & -0.0031 \\
$(-0.111)$ & $(-1.024)$ \\
0.0012 & $0.0041 *$ \\
$(0.032)$ & $(1.728)$ \\
& \\
&
\end{tabular}

\begin{tabular}{rr}
\hline \multicolumn{2}{c}{ GCC Firms } \\
\hline CEO & CEO Duality \\
Duality $=\mathbf{0}$ & \multicolumn{1}{c}{$\mathbf{1}$} \\
\hline $\mathbf{0 . 5 2 8 3} * *$ & $\mathbf{0 . 9 8 1 1 * * *}$ \\
$\mathbf{( 1 . 9 8 4 )}$ & $\mathbf{( 4 . 9 6 2 )}$ \\
0.0139 & $\mathbf{0 . 4 2 9 5 * * *}$ \\
$(0.000)$ & $\mathbf{( 3 . 1 4 2 )}$ \\
0.0285 & $-0.4833 * *$ \\
$(0.000)$ & $(2.125)$ \\
-0.0477 & 0.0210 \\
$(0.236)$ & $(0.431)$ \\
$\mathbf{0 . 5 8 9 1 * * *}$ & 0.0146 \\
$\mathbf{( 4 . 6 7 8 )}$ & $(0.008)$ \\
$\mathbf{0 . 3 2 0 8} * * *$ & $\mathbf{0 . 4 7 1 0 * * *}$ \\
$\mathbf{( 4 . 9 8 8 )}$ & $\mathbf{( 7 . 6 2 9 )}$ \\
-0.0199 & $\mathbf{- 0 . 0 7 4 2 *}$ \\
$(1.052)$ & $(\mathbf{1 . 7 6 9 )}$ \\
0.0182 & 0.0295 \\
$(0.033)$ & $(1.381)$ \\
-0.0223 & -0.0176 \\
$(0.451)$ & $(0.143)$ \\
-0.0282 & $\mathbf{- 0 . 2 8 1 0 * * *}$ \\
$(0.031)$ & $\mathbf{( 3 . 7 6 1 )}$ \\
-0.0257 & $0.1459 * *$ \\
$(0.132)$ & $(2.165)$ \\
0.0845 & -0.0281 \\
$(0.012)$ & $(0.026)$ \\
-0.0094 & -0.0128 \\
$(0.198)$ & $(0.351)$ \\
0.0319 & 0.0783 \\
$(0.087)$ & $(0.025)$ \\
&
\end{tabular}




\begin{tabular}{lrrrrrrr} 
Constant & -0.02935 & 0.0543 & -0.0392 & 0.0446 & 0.0176 & $0.0342^{* * *}$ \\
& $(-0.512)$ & $(0.282)$ & $(0.493)$ & $(0.02)$ & $(0.312)$ & $(3.938)$ \\
\hline R-squared & $\mathbf{0 . 3 9 0 1}$ & $\mathbf{0 . 2 8 3 0}$ & $\mathbf{0 . 3 1 7 5}$ & $\mathbf{0 . 2 6 5 8}$ & $\mathbf{0 . 3 4 2 0}$ & $\mathbf{0 . 3 9 4 5}$ \\
\hline Wald-Test & $193.66^{* * *}$ & $121.98^{* * *}$ & $157.93^{* * *}$ & $114.92^{* * *}$ & $172.09^{* * *}$ & $210.29^{* * *}$ \\
\hline Obs. & 1414 & 1861 & 804 & 950 & 610 & 911 \\
\hline
\end{tabular}

Panel B. Impact on Dividend Decision

\begin{tabular}{|c|c|c|c|c|c|c|}
\hline \multirow[t]{2}{*}{ D_Dec } & \multicolumn{2}{|c|}{ All Firms } & \multicolumn{2}{|c|}{ East Asian Firms } & \multicolumn{2}{|l|}{ GCC Firms } \\
\hline & $\begin{array}{c}\text { CEO } \\
\text { Duality }=0\end{array}$ & $\begin{array}{c}\text { CEO } \\
\text { Duality }=1\end{array}$ & $\begin{array}{c}\text { CEO } \\
\text { Duality }=0\end{array}$ & $\begin{array}{c}\text { CEO } \\
\text { Duality }=1\end{array}$ & $\begin{array}{c}\text { CEO } \\
\text { Duality }=0\end{array}$ & $\begin{array}{c}\text { CEO } \\
\text { Duality }=1\end{array}$ \\
\hline Inst_Own & $\begin{array}{r}0.3258 * * \\
(1.228)\end{array}$ & $\begin{array}{r}0.5239 * * * * \\
(2.869)\end{array}$ & $\begin{array}{r}0.4581 * * \\
(2.187)\end{array}$ & $\begin{array}{r}0.6720 * * * * \\
(3.651)\end{array}$ & $\begin{array}{l}0.0161 \\
(0.051)\end{array}$ & $\begin{array}{r}0.3183 * * * \\
(3.129)\end{array}$ \\
\hline \multirow[t]{2}{*}{ Conc } & 0.1052 & $-0.0153 * *$ & 0.0247 & $-0.2133 * * *$ & 0.1916 & $-0.3264 * * *$ \\
\hline & $(0.045)$ & (2.182) & $(0.093)$ & (2.986) & $(0.043)$ & (3.186) \\
\hline \multirow[t]{2}{*}{ TOP5.Shar } & 0.2849 & $-1.9634 * *$ & -0.6847 & $-1.7481 * *$ & $0.6847 * *$ & $-1.7634 * * *$ \\
\hline & $(0.108)$ & $(-2.201)$ & $(0.439)$ & (1.901) & (2.147) & (4.601) \\
\hline \multirow[t]{2}{*}{ Mang_Own } & -0.0298 & 0.5295 & 0.0675 & 0.3622 & -0.0675 & 0.3673 \\
\hline & $(-0.005)$ & $(0.025)$ & $(0.004)$ & $(0.1753)$ & $(0.003)$ & $(0.063)$ \\
\hline \multirow[t]{2}{*}{ Int } & $0.0473 * * *$ & 0.0527 & $0.2154 * * *$ & 0.0369 & $0.0473 * * *$ & 0.0367 \\
\hline & (3.957) & (1.102) & $(6.813)$ & $(0.276)$ & (3.737) & $(0.106)$ \\
\hline \multirow[t]{2}{*}{ Board_size } & $0.1058 * * *$ & $0.7384 * * *$ & $0.2816 * * *$ & $1.3591 * * *$ & $0.2419 * * *$ & $0.5720 * * *$ \\
\hline & (9.213) & (5.049) & (3.618) & (5.099) & (7.613) & (3.047) \\
\hline \multirow[t]{2}{*}{ Board_indep } & -0.0094 & $-0.0938 * *$ & -0.0281 & $-0.1638 * * *$ & -0.0921 & $-0.715 * *$ \\
\hline & $(-1.14)$ & $(-2.174)$ & $(0.007)$ & (3.153) & $(0.006)$ & (2.848) \\
\hline \multirow[t]{2}{*}{ firm_age } & $0.0524 * * *$ & $0.05325 * * *$ & $0.0296 * * *$ & $0.0278 * * *$ & $0.03684 * * *$ & $0.0321 * * *$ \\
\hline & $(0.295)$ & $(0.320)$ & $(6.435)$ & (3.129) & (2.673) & (3.005) \\
\hline Beta & $\begin{array}{r}-0.1105 * * * \\
(-0.591)\end{array}$ & $\begin{array}{r}-0.1132 * * * \\
(-5.082)\end{array}$ & $\begin{array}{r}-0.4572 * * * \\
(4.371)\end{array}$ & $\begin{array}{r}-0.2986 * * * \\
(3.086)\end{array}$ & $\begin{array}{r}-0.1758 \\
(1.379)\end{array}$ & $\begin{array}{r}-0.1642 * * * \\
(3.154)\end{array}$ \\
\hline \multirow[t]{2}{*}{ Firm_size } & 0.0065 & 0.0281 & 0.0286 & 0.0725 & 0.0146 & 0.0798 \\
\hline & $(0.343)$ & (1.105) & $(0.343)$ & -1.103 & $(0.343)$ & (1.103) \\
\hline \multirow[t]{2}{*}{ ROE } & 0.0768 & -0.0239 & 0.0768 & -0.0637 & 0.0768 & 0.0682 \\
\hline & $(0.339)$ & $(-0.815)$ & $(0.337)$ & $(-0.813)$ & $(0.527)$ & $(0.713)$ \\
\hline \multirow[t]{2}{*}{ Tax } & 0.0521 & -0.1493 & 0.0361 & -0.1473 & 0.0361 & -0.1855 \\
\hline & $(0.265)$ & $(-0.337)$ & $(0.653)$ & $(-0.311)$ & $(0.523)$ & $(0.337)$ \\
\hline \multirow[t]{2}{*}{ Debt } & 0.0002 & -0.4391 * & 0.0025 & 0.3341 & 0.0007 & -0.4371 * \\
\hline & $(0.254)$ & $(-1.972)$ & $(0.734)$ & $(0.737)$ & $(0.734)$ & (1.231) \\
\hline \multirow[t]{2}{*}{ Industry } & -0.0472 & 0.0975 & $(0.0257)$ & 0.0873 & -0.0477 & 0.0773 \\
\hline & $(-1.185)$ & $(0.129)$ & (1.137) & $(0.192)$ & $(1.233)$ & $(0.082)$ \\
\hline \multirow[t]{2}{*}{ Region } & 0.0827 & 0.0375 & --- & --- & --- & --- \\
\hline & $(0.002)$ & $(0.008)$ & & & & \\
\hline \multirow[t]{2}{*}{ Constant } & $-1.0281 * * *$ & -0.2035 & -1.0731 & -0.4981 & $-1.0731 * * *$ & -0.7049 \\
\hline & $(-5.032)$ & $(-0.065)$ & $(\mathbf{0 . 0 3 7 )}$ & $(0.073)$ & $(3.689)$ & $(0.108)$ \\
\hline R-squared & 0.3565 & 0.4353 & 0.3198 & 0.3820 & 0.2866 & 0.3941 \\
\hline Wald-Test & $181.39 * * *$ & $252.45^{* * * *}$ & $145.36^{* * *}$ & $142.81 * * *$ & $139.26^{* * *}$ & $193.01 * * *$ \\
\hline
\end{tabular}




\begin{tabular}{lllllll}
\hline Obs. & 1414 & 1861 & 804 & 950 & 610 & 911 \\
\hline
\end{tabular}

The intensity of the board confirms our basic hypothesis only for firms without CEO duality. In fact, this variable appears significantly positive only for firms without CEO duality. For these firms, the agency conflict may be more intense, and dividend policy is considered as a solution to reduce the cost of subsequent agency. In this case, shareholders require a higher dividend yield. The intensity of the board of directors has a significant impact on both kinds of firms in the East Asian region. Instead, only firms with CEO duality appear to be affected by the intensity of the board of directors.

The Beta coefficient shows different impacts on the dividend yields of firms in the East Asian and GCC regions. This coefficient significantly affects all firms in the East Asian countries, while it appears significant only for firms with CEO duality in the case of GCC countries.

Table 5 also shows that the Region coefficient significantly and positively affects dividend yields. This implies that firms in the GCC countries tend to offer higher payouts than firms in East Asia.

\section{The impact of crisis on the relationship between board governance and dividend policy}

In order to test the impact of board governance on dividend policy during the most recent crisis period, we run our basic model by adding a new variable - Crisis - to the regressions. This variable should capture the impact of the financial crisis and economic slowdown on firms' dividend policy. The variable Crisis takes the value of 1 for the 2007-2010 period and 0 otherwise. Furthermore, to control whether the impact of ownership structure and corporate governance on dividend policy changes during the crisis period, we interact ownership structure and corporate governance variables with the Crisis variable. The results are shown in Table 6 . The results show that the impact of the crisis is more relevant for the dividend policies of firms in GCC countries.

Table 6 shows that board size has significant and negative effects on firm dividend decisions in both regions when interacted with the crisis variable. The impact appears more significant in the GCC countries. The same variable appears negative but non-significant when it is not interacted with the crisis variable. This shows that board size is more relevant in the emerging markets during the financial crisis. This negative relationship can be explained by the fact that during the 
crisis, board members become more risk averse, which is a sign of better company governance. These companies seek to protect their shareholders during periods of high uncertainty by reinvesting their earnings internally.

Regarding Dividend yields, the interacted coefficients of CEO Duality with crisis are negatively significant at the 10\% and 1\% levels for the East Asian and the GCC countries, respectively. This implies that during crisis periods, firms with CEO duality pay lower cash dividends. This explanation can be interpreted to mean that during crisis periods, it is difficult for firms to raise external funds to support their growth; accordingly, CEOs prefer to reduce their dividend payouts. This implies that CEOs who are also chairmen of the board of directors can exercise more control over their firms and may be less likely to have their dividend policy decisions challenged by the board of directors.

Another interesting result is that the interacted coefficient of board intensity has a significantly negative effect on both firms' dividend payouts and dividend decisions in the GCC countries. For the East Asian countries, the impact is significant only for dividend yield payouts. This finding implies that firms with active boards were less likely to pay out dividends during the recent financial crisis. The purpose of having more board meetings during the financial crisis was to establish policies that protect shareholders and sustain the financial stability of the firm.

\section{Table 6. Board governance, ownership structure and dividend policy: impact of crisis}

This table reports the GMM fixed effects panel model estimation. The model sets the relationship between board governance and dividend policy for a sample of 362 non-financial firms over the 2003-2011 period. Dependent variables are Dividend decision (D_Dec) and dividend yield (D_Yield), respectively. Definitions of all variables are reported in table 1. Tstatistics are reported in parentheses. $* * *, * * *$ indicate significance at the 1,5 and 10 percent levels of significance, respectively.

\begin{tabular}{|c|c|c|c|c|}
\hline \multirow[b]{2}{*}{ Independent variable } & \multicolumn{2}{|c|}{ D_Dec } & \multicolumn{2}{|c|}{ D_Yield } \\
\hline & $\begin{array}{c}\text { East Asian } \\
\text { countries }\end{array}$ & GCC Countries & $\begin{array}{r}\text { East Asian } \\
\text { countries }\end{array}$ & GCC Countries \\
\hline \multirow[t]{2}{*}{ Duality } & $0.8390 * * *$ & $0.7641 * * *$ & $0.2614 * * *$ & $0.1843 * * *$ \\
\hline & $(4.252)$ & (3.840) & (3.173) & (6.923) \\
\hline \multirow[t]{2}{*}{ Int } & $0.0684 * * *$ & $0.05382 * * *$ & $0.9838 * * *$ & $0.2308 * * *$ \\
\hline & $(5.728)$ & $(8.055)$ & $(3.728)$ & (3.538) \\
\hline \multirow[t]{2}{*}{ Board_size } & 0.9315 & -0.0843 & 0.0627 & 0.8263 \\
\hline & $(01.54)$ & $(0.067)$ & $(0.111)$ & $(0.850)$ \\
\hline \multirow[t]{2}{*}{ Board_indep } & $-0.0478 * * *$ & $-0.1754 * * *$ & $-0.0471 * * *$ & $-0.1523 * * *$ \\
\hline & $(-2.825)$ & $(-8.022)$ & $(-3.878)$ & $(-3.678)$ \\
\hline \multirow[t]{2}{*}{ Crisis } & $-0.8154 * * *$ & $0.3645^{* * *}$ & $-0.0433 * * *$ & -0.07543 \\
\hline & $(-5.20)$ & $(3.180)$ & $(-3.71)$ & $(-0.84)$ \\
\hline \multirow[t]{2}{*}{ Duality*Crisis } & $-0.0060 * *$ & $-0.1856 * *$ & $-0.1856 * *$ & $-0.0560 * * *$ \\
\hline & $(-1.920)$ & $(-2.304)$ & $(-2.14)$ & $(-3.943)$ \\
\hline \multirow[t]{2}{*}{ Int ${ }^{*}$ Crisis } & -0.6726 & $-0.6841 * * *$ & $-0.6841 * * *$ & $-0.8728 * * *$ \\
\hline & $(0.016)$ & (3.221) & (4.729) & (2.958) \\
\hline \multirow{2}{*}{ Board_size*Crisis } & $-0.2916^{* *}$ & $-0.4635 * * *$ & $-0.0935 * * *$ & -0.0018 \\
\hline & $(-2.327)$ & $(-2.754)$ & $(-3.825)$ & $(-0.047)$ \\
\hline \multirow[t]{2}{*}{ Board_indep*Crisis } & 0.00162 & 0.0629 & 0.0183 & 0.00184 \\
\hline & $(0.002)$ & (1.178) & $(0.067)$ & $(0.034)$ \\
\hline Mang_Own*Crisis & $-0.7001 * * *$ & $-0.3229 * * *$ & $-0.5226^{* * *}$ & $-0.4332 * * *$ \\
\hline
\end{tabular}




\begin{tabular}{|c|c|c|c|c|}
\hline & (4.197) & $(3.945)$ & $(5.049)$ & (7.261) \\
\hline \multirow[t]{2}{*}{ Inst_Own*Crisis } & $1.2691 * * *$ & 0.5321 & $0.7521 * * *$ & 1.481 \\
\hline & $(4.206)$ & (1.008) & $(3.075)$ & $(0.036)$ \\
\hline \multirow[t]{2}{*}{ Conc $*$ Crisis } & 0.0291 & 0.0923 & 0.0692 & 0.3491 \\
\hline & $(0.026)$ & $(0.0043)$ & $(0.0613)$ & $(0.028)$ \\
\hline \multirow[t]{2}{*}{ TOP5_Shar*Crisis } & -0.076 & -0.0359 & -0.0576 & -0.576 \\
\hline & $(-0.690)$ & $(-0.011)$ & $(-0.081)$ & $(-0.543)$ \\
\hline \multirow[t]{2}{*}{ Inst_Own } & $0.5794 * * *$ & $0.4691 * * *$ & $0.0238 * * *$ & $0.0743 * * *$ \\
\hline & (8.708) & $(\mathbf{2 . 4 5 1 )}$ & (3.524) & (3.238) \\
\hline \multirow[t]{2}{*}{ Conc } & $2.9342 * * *$ & $0.7945 * *$ & $0.0673 * *$ & $0.9076 * * *$ \\
\hline & (11.54) & $(2.088)$ & (1.993) & $(3.941)$ \\
\hline \multirow[t]{2}{*}{ TOP5_Shar } & 0.0362 & -0.0406 & $-0.0753 * *$ & $-0.0383^{*}$ \\
\hline & $(0.091)$ & $(-0.511)$ & $(-3.810)$ & $(-1.783)$ \\
\hline \multirow[t]{2}{*}{ Mang_Own } & 0.15674 & 0.0850 & -0.0938 & $-0 . .0758$ \\
\hline & $(0.089)$ & $(0.481)$ & $(-0.318)$ & $(-0.473)$ \\
\hline \multirow[t]{2}{*}{ firm_age } & $0.0978 * * *$ & $0.0684 * * *$ & 0.0738 & 0.0074 \\
\hline & $(5.308)$ & (4.951) & $(0.433)$ & $(0.008)$ \\
\hline \multirow[t]{2}{*}{ Beta } & $-0.0832 *$ & -0.0648 & 0.6238 & 0.0254 \\
\hline & $(-1.048)$ & $(-1.551)$ & $(0.481)$ & $(0.637)$ \\
\hline \multirow[t]{2}{*}{ Firm_size } & $0.0728 * *$ & $-0.0357 * * *$ & $-0.8734 * *$ & $-0.9834 * * *$ \\
\hline & $(1.951)$ & $(2.721)$ & $(-4.628)$ & $(-3.138)$ \\
\hline \multirow[t]{2}{*}{ ROE } & 0.0610 & 0.0351 & -0.06388 & -0.0383 \\
\hline & $(0.650)$ & $(0.861)$ & $(-0.004)$ & $(-0.018)$ \\
\hline \multirow[t]{2}{*}{ Tax } & 0.0281 & -0.0258 & 0.0064 & 0.0084 \\
\hline & $(0021)$ & $(-0.025)$ & $(1.181)$ & $(0.513)$ \\
\hline \multirow[t]{2}{*}{ Debt } & -1.0007 & -1.0083 & -0.0006 & -0.0065 \\
\hline & $(-1.088)$ & $(-1.075)$ & $(-1.030)$ & $(-0.911)$ \\
\hline \multirow[t]{2}{*}{ Industry } & -0.3599 & -0.0091 & 0.0006 & 0.0067 \\
\hline & $(-0.148)$ & $(-0.788)$ & (1.203) & $(0.010)$ \\
\hline \multirow[t]{2}{*}{ Constant } & $-0.3961 * * *$ & $-0.6315 * * *$ & 0.0143 & 0.0678 \\
\hline & $(-4.384)$ & $(-4.524)$ & $(0.788)$ & $(0.181)$ \\
\hline R-squared Within & 0.2185 & 0.2916 & 0.2733 & 0.3248 \\
\hline Wald-Test & $143.80^{* * *}$ & $193.14^{* * *}$ & $163.96^{* * *}$ & $241.72 * * *$ \\
\hline Obs. & 1414 & 1861 & 804 & 950 \\
\hline
\end{tabular}

Contrary to previous results, managerial ownership has a significant negative effect on dividend payouts when interacted with the crisis variable for firms in both regions. This is consistent with several previous studies and confirms our basic hypothesis. Demsetz and Lehn (1985) suggest that managerial ownership is an important internal monitoring force that is particularly important in times of crisis when other governance mechanisms are not very functional. They defend that managerial ownership is an effective monitoring tool for resolving the agency conflicts between external stockholders and managers during crisis periods.

Contrary to GCC firms, institutionals have a significantly positive effect on dividend yields in the crisis period for firms in East Asian countries. This implies that during turbulent periods, institutionals require higher cash dividends in order to reduce the risk of expropriation and to increase shareholder profitability. This finding is in line with the arguments of Jensen (1986) supporting that dividend can be used by institutionals as a mechanism to reduce agency problems between shareholders and managers. The Concentration variable interacted with crisis appears insignificant and does not affect the dividend or the dividend yield decisions of firms in both regions. 
The results for the control variables are in line with previous regressions. Again, firm age is positively and significantly related to the dividend decision measure. Beta and firm size are negative and highly significant. As before, the remaining control variables are statistically insignificant.

\section{The effect of CEO Duality on dividend policy during the crisis:}

To investigate in greater depth whether the crisis had an effect on the relationship between board governance and dividend policy, we again split our sample into two sub-samples: the first with CEO duality and the second without CEO duality.

The results are reported in table 7. Panel A and Panel B estimate the model with the dividend yield and dividend decision as dependent variables, respectively. Regarding firms without CEO Duality, the coefficient of board intensity interacted with crisis appears significantly negative at the $1 \%$ level. This result shows that companies with more board meetings were less likely to pay out dividends during the most recent financial crisis. This finding supports that better-governed companies are more risk averse and, consequently, preferred not to pay dividends in the crisis period. This result is particularly confirmed for East Asian firms, which are the only firms for which CEO 
Table 7. Regression results of the effect of CEO Duality on dividend policy during the crisis. This table reports the GMM fixed effects panel model estimation. The model sets the relationship between board governance and dividend policy for a sample of 362 non-financial firms over the 2003-2011 period. The dependent variable in Panel A is the dividend yield (D_Yield) and that in Panel B is the Dividend decision (D_Dec). Definitions of all variables are reported in table 1. t-statistics are reported in parentheses. ${ }^{* * *}, *^{*},{ }^{*}$ indicate significance at the 1,5 and 10 percent levels of significance, respectively.

Panel A. Impact on Dividend Yield

All Firms

East Asian Firms

GCC Firms

\begin{tabular}{|c|c|c|c|c|c|c|}
\hline Independent variable & CEO Duality $=0$ & CEO Duality = 1 & CEO Duality $=0$ & CEO Duality $=1$ & CEO Duality $=0$ & CEO Duality $=1$ \\
\hline \multirow{2}{*}{ Int } & $0.8031 *$ & 0.0562 & $0.7671^{*}$ & 0.42839 & $0.3761 * * *$ & 0.1732 \\
\hline & $(1.682)$ & $(0.276)$ & $(1.792)$ & $(0.246)$ & $(3.5611)$ & $(0.76)$ \\
\hline \multirow{2}{*}{ Board_size } & $0.0496^{* * *}$ & $0.7054 * * *$ & $0.1058^{* * *}$ & $0.4076 * * *$ & $0.0462 * * *$ & $0.5429 * * *$ \\
\hline & $(4.003)$ & $(3.361)$ & $(3.064)$ & $(3.161)$ & $(4.215)$ & $(5.527)$ \\
\hline \multirow{2}{*}{ Board_indep } & -0.0042 & $-0.0068^{* *}$ & -0.0198 & $-0.1751 * *$ & -0.1471 & $-0.2728 * * *$ \\
\hline & $(-1.096)$ & $(-2.274)$ & $(0.572)$ & (3.248) & $(-1.062)$ & $(-2.754)$ \\
\hline \multirow{2}{*}{ Crisis } & -0.0024 & -0.0123 & -0.0175 & -0.0133 & -0.0024 & -0.0129 \\
\hline & $(-0.940)$ & $(-0.262)$ & $(0.883)$ & $(0.297)$ & $(-0.640)$ & $(0.530)$ \\
\hline \multirow{2}{*}{ Int*Crisis } & $-0.9867 * * *$ & -0.0390 & $-0.2784 * * *$ & -0.0154 & -0.6825 & -0.0560 \\
\hline & $(7.0591)$ & $(0.034)$ & $(3.0691)$ & $(0.228)$ & $(0.042)$ & $(0.064)$ \\
\hline \multirow{2}{*}{ Board_size*Crisis } & $-0.8611 * * *$ & -0.0063 & $-0.1611^{* * *}$ & -0.0538 & $-0.8211 * * *$ & -0.0026 \\
\hline & $(-4.042)$ & $(-0.170)$ & $(3.868)$ & $(0.145)$ & $(4.042)$ & $(0.160)$ \\
\hline \multirow{2}{*}{ Board_indep*Crisis } & 0.0860 & 0.0065 & 0.012 & 0.0416 & 0.0553 & 0.0026 \\
\hline & $(0.901)$ & $(0.042)$ & $(0.001)$ & $(0.058)$ & $(0.891)$ & $(0.172)$ \\
\hline \multirow[t]{2}{*}{ Conc* Crisis } & 0.0714 & $0.8305^{* * *}$ & 0.0419 & $0.1479^{* * *}$ & $0.0934^{* *}$ & $0.8216^{* * *}$ \\
\hline & $(0.983)$ & $(3.052)$ & $(0.267)$ & (3.754) & $(2.321)$ & (6.196) \\
\hline \multirow[t]{2}{*}{ TOP5_Shar*Crisis } & 0.0984 & $0.7983^{* * *}$ & 0.0914 & $0.4911^{* * *}$ & 0.0695 & $0.6916^{* * *}$ \\
\hline & $(0.249)$ & $(2.892)$ & $(0.226)$ & $(2.850)$ & $(0.316)$ & $(2.962)$ \\
\hline \multirow[t]{2}{*}{ Inst_Own*Crisis } & 0.8530 & 0.0127 & 0.1557 & 0.1624 & 0.8720 & 0.0126 \\
\hline & $(0.007)$ & $(0.967)$ & $(0.004)$ & $(0.964)$ & $(0.011)$ & $(0.623)$ \\
\hline \multirow[t]{2}{*}{ Mang_Own*Crisis } & 0.0742 & 0.0864 & 0.0442 & $0.0164 * *$ & 0.0695 & 0.0729 \\
\hline & $(0.005)$ & $(0.001)$ & $(0.006)$ & $(2.045)$ & $(0.016)$ & $(0.051)$ \\
\hline \multirow{2}{*}{ Inst_Own. } & $0.0483 * *$ & $0.04932 * *$ & $0.0411 * *$ & $0.04712 * *$ & $0.0986 * *$ & $0.09662 * *$ \\
\hline & (2.309) & $(2.274)$ & (2.195) & (2.244) & (2.636) & (2.269) \\
\hline \multirow{2}{*}{ Conc } & -0.0152 & 0.0034 & -0.0162 & 0.0014 & -0.0172 & 0.0079 \\
\hline & $(-1.049)$ & $(0.262)$ & $(1.517)$ & $(0.262)$ & $(1.336)$ & $(0.233)$ \\
\hline \multirow{2}{*}{ TOP5_Shar } & 0.0092 & -0.0212 & 0.0072 & -0.0212 & 0.0178 & -0.0212 \\
\hline & $(0.021)$ & $(-0.061)$ & $(0.021)$ & $(-0.061)$ & $(0.074)$ & $(0.811)$ \\
\hline \multirow{2}{*}{ Mang_Own } & -0.0127 & 0.02823 & -0.0124 & 0.0351 & -0.0127 & 0.0942 \\
\hline & $(-0.498)$ & $(1.262)$ & $(-0.371)$ & (1.843) & $(-0.968)$ & (1.852) \\
\hline \multirow{2}{*}{ firm_age } & 0.0039 & 0.0639 & 0.0017 & 0.0617 & 0.0136 & 0.0276 \\
\hline & $(0.004)$ & $(0.982)$ & $(0.015)$ & $(0.352)$ & (0.009) & $(0.682)$ \\
\hline \multirow{2}{*}{ Beta } & 0.0796 & 0.0072 & 0.0476 & 0.00422 & 0.0562 & 0.0093 \\
\hline & $(0.040)$ & $(0.271)$ & $(0.020)$ & $(0.241)$ & $(0.380)$ & $(0.198)$ \\
\hline \multirow{2}{*}{ Firm_size } & -0.00364 & $-0.0742 * * *$ & -0.0375 & $-0.0442 * * *$ & $-0.0403^{*}$ & $-0.1952 * * *$ \\
\hline & $(-0.674)$ & $(-2.294)$ & $(0.247)$ & (4.931) & (1.694) & $(3.269)$ \\
\hline \multirow{2}{*}{ ROE } & 0.0002 & 0.0031 & 0.0903 & 0.0849 & 0.0328 & 0.0071 \\
\hline & $(0.074)$ & $(0.272)$ & $(0.124)$ & $(0.007)$ & $(0.031)$ & $(0.262)$ \\
\hline \multirow{2}{*}{ Tax } & 0.0054 & 0.0534 & 0.0738 & 0.0614 & 0.0079 & 0.0579 \\
\hline & $(0.809)$ & $(0.263)$ & $(0.152)$ & $(0.261)$ & $(0.355)$ & $(0.237)$ \\
\hline & -0.3234 & -0.0035 & -0.1214 & -0.0128 & $-0.6812^{* *}$ & -0.1837 \\
\hline Debt & $(-0.49)$ & $(-1.719)$ & $(0.47)$ & (1.417) & (1.973) & $(-1.754)$ \\
\hline & 0.0008 & -0.1674 & 0.0001 & -0.1644 & 0.0439 & -0.1598 \\
\hline Industry & $(0.720)$ & $(-0.292)$ & $(0.420)$ & $(0.438)$ & $(0.983)$ & $(0.382)$ \\
\hline Region & $0.1216^{* *}$ & $0.9814^{* * *}$ & --- & --- & --- & --- \\
\hline & (1.981) & (3.0561) & & & & \\
\hline Constant & 0.0221 & 0.02632 & 0.1861 & 0.1876 & 0.1893 & 0.0541 \\
\hline Constant & $(0.004)$ & $(0.022)$ & $(0.025)$ & $(0.587)$ & $(0.876)$ & $(0.142)$ \\
\hline R-squared & 0.2938 & 0.2744 & 0.3491 & 0.3261 & 0.3198 & 0.3671 \\
\hline Wald-Test & $129.36^{* * *}$ & $123.76^{* * *}$ & $231.62^{* * *}$ & $162.84^{* * *}$ & $149.01^{* * *}$ & $259.44 * * *$ \\
\hline
\end{tabular}




\begin{tabular}{|c|c|c|c|c|c|c|}
\hline \multirow{2}{*}{\multicolumn{7}{|c|}{$\begin{array}{lr}\text { Obs. } & 1414 \\
\text { Panel B. Impact on Dividend Decision }\end{array}$}} \\
\hline & & & & & & \\
\hline Independent variable & $\begin{array}{c}\text { CEO } \\
\text { Duality }=0\end{array}$ & CEO Duality $=1$ & $\begin{array}{c}\text { CEO } \\
\text { Duality }=0\end{array}$ & $\begin{array}{c}\text { CEO } \\
\text { Duality }=1\end{array}$ & $\begin{array}{c}\text { CEO Duality }= \\
0\end{array}$ & $\begin{array}{l}\text { CEO Duality } \\
\quad=1\end{array}$ \\
\hline Int & $\begin{array}{r}0.0644^{* * * *} \\
(6.410)\end{array}$ & $\begin{array}{r}0.0374^{* * * *} \\
(3.891)\end{array}$ & $\begin{array}{r}0.2518 * * * \\
(7.835)\end{array}$ & $\begin{array}{r}0.0378^{* * * *} \\
(3.391)\end{array}$ & $\begin{array}{r}0.1739 * * * \\
(4.410)\end{array}$ & $\begin{array}{r}0.2895^{* * * k} \\
(3.275)\end{array}$ \\
\hline Board_size & $\begin{array}{r}0.1162 * * * * \\
(4.219)\end{array}$ & $\begin{array}{r}0.0298^{* * *} \\
(6.082)\end{array}$ & $\begin{array}{r}0.1842 * * * \\
(2.945)\end{array}$ & $\begin{array}{r}0.0293 * * * \\
(3.482)\end{array}$ & $\begin{array}{r}0.1722 * * * \\
(3.215)\end{array}$ & $\begin{array}{r}0.1640 * * * \\
(5.942)\end{array}$ \\
\hline Board_indep & $\begin{array}{r}-0.03686 \\
(-0.601)\end{array}$ & $\begin{array}{r}-0.0225^{* *} \\
(-2.148)\end{array}$ & $\begin{array}{r}-0.1854 \\
(0.739)\end{array}$ & $\begin{array}{r}-0.4126 * * \\
(2.042)\end{array}$ & $\begin{array}{r}-0.1089 \\
(0.401)\end{array}$ & $\begin{array}{r}-0.1855^{* * *} \\
(3.148)\end{array}$ \\
\hline Crisis & $\begin{array}{r}0.16031 \\
(0.048)\end{array}$ & $\begin{array}{l}-0.0314 \\
(-0.019)\end{array}$ & $\begin{array}{l}0.0792 \\
(0.003)\end{array}$ & $\begin{array}{r}-0.0548 \\
(0.042)\end{array}$ & $\begin{array}{l}0.1483 \\
(0.055)\end{array}$ & $\begin{array}{l}-0.0891 \\
(-0.019)\end{array}$ \\
\hline Int ${ }^{*}$ Crisis & $\begin{array}{r}-0.6914 * * * \\
(-2.823)\end{array}$ & $\begin{array}{l}-0.0526 \\
(-0.024)\end{array}$ & $\begin{array}{r}-0.7258 * * * \\
(-2.323)\end{array}$ & $\begin{array}{l}-0.1427 \\
(-0.053)\end{array}$ & $\begin{array}{r}-0.4326 * * * \\
(2.761)\end{array}$ & $\begin{array}{r}-0.0526 \\
(0.374)\end{array}$ \\
\hline Board_size* Crisis & $\begin{array}{r}-0.2371^{* *} \\
(-3.810)\end{array}$ & $\begin{array}{r}-0.0832 \\
(-1.0301)\end{array}$ & $\begin{array}{r}-0.1899 * * \\
(-3.358)\end{array}$ & $\begin{array}{r}-0.0362 \\
(-1.0301)\end{array}$ & $\begin{array}{r}-0.2395^{* * *} \\
(3.769)\end{array}$ & $\begin{array}{r}-0.0854 \\
(1.175)\end{array}$ \\
\hline Board_indep*Crisis & $\begin{array}{r}0.04324 \\
(1.37)\end{array}$ & $\begin{array}{r}0.00316 \\
(0.169)\end{array}$ & $\begin{array}{r}0.08228 \\
(1.27)\end{array}$ & $\begin{array}{r}0.00217 \\
(0.179)\end{array}$ & $\begin{array}{r}0.04324 \\
(1.38)\end{array}$ & $\begin{array}{r}0.00316 \\
(0.169)\end{array}$ \\
\hline Conc* Crisis & $\begin{array}{l}-0.5338 \\
(0.251)\end{array}$ & $\begin{array}{r}0.2391 * * * \\
(11.0478)\end{array}$ & $\begin{array}{l}-0.6267 \\
(0.267)\end{array}$ & $\begin{array}{r}0.2741^{* * *} \\
(8.072)\end{array}$ & $\begin{array}{l}0.3067 \\
(0.063)\end{array}$ & $\begin{array}{r}0.2975^{* * *} \\
(4.612)\end{array}$ \\
\hline TOP5_Shar*Crisis & $\begin{array}{l}0.0983 \\
(0.308)\end{array}$ & $\begin{array}{r}0.7791 * * \\
(1.994)\end{array}$ & $\begin{array}{l}0.0442 \\
(0.202)\end{array}$ & $\begin{array}{r}0.2151^{* *} \\
(1.998)\end{array}$ & $\begin{array}{l}0.0573 \\
(0.356)\end{array}$ & $\begin{array}{r}0.7342^{* * *} \\
\quad(3.943)\end{array}$ \\
\hline Inst_Own*Crisis & $\begin{array}{r}-0.7624 \\
(0.905)\end{array}$ & $\begin{array}{l}0.0679 \\
(0.469)\end{array}$ & $\begin{array}{r}-0.5348 \\
(0.718)\end{array}$ & $\begin{array}{l}0.0573 \\
(0.879)\end{array}$ & $\begin{array}{r}-0.8493 \\
(0.577)\end{array}$ & $\begin{array}{l}0.0842 \\
(0.362)\end{array}$ \\
\hline Mang_Own*Crisis & $\begin{array}{l}0.0735 \\
(0.308)\end{array}$ & $\begin{array}{l}0.3572 \\
(0.865)\end{array}$ & $\begin{array}{l}0.0726 \\
(0.202)\end{array}$ & $\begin{array}{l}0.2672 \\
(0.256)\end{array}$ & $\begin{array}{l}0.0821 \\
(0.453)\end{array}$ & $\begin{array}{l}0.8642 \\
(0.366)\end{array}$ \\
\hline Inst_Own. & $\begin{array}{r}0.34814 \\
(1.286)\end{array}$ & $\begin{array}{r}0.9636 * * \\
(2.232)\end{array}$ & $\begin{array}{r}0.28218^{* * * *} \\
(4.237)\end{array}$ & $\begin{array}{r}0.9525^{* *} \\
(2.172)\end{array}$ & $\begin{array}{l}0.2298 \\
(1.091)\end{array}$ & $\begin{array}{r}0.6636^{* * *} \\
(2.051)\end{array}$ \\
\hline Conc & $\begin{array}{r}-0.02324 \\
(-0.023)\end{array}$ & $\begin{array}{l}-0.0245 \\
(-0.020)\end{array}$ & $\begin{array}{l}-0.0236 \\
(-0.022)\end{array}$ & $\begin{array}{l}-0.0286 \\
(-0.020)\end{array}$ & $\begin{array}{r}-0.0987 \\
(0.290)\end{array}$ & $\begin{array}{l}-0.1392 \\
(0.150)\end{array}$ \\
\hline TOP5_Shar & $\begin{array}{r}0.22893 \\
(0.263)\end{array}$ & $\begin{array}{l}-0.9286 \\
(-1.229)\end{array}$ & $\begin{array}{r}0.21852 \\
(0.252)\end{array}$ & $\begin{array}{l}-0.9237 \\
(-1.419)\end{array}$ & $\begin{array}{l}0.3965 \\
(0.049)\end{array}$ & $\begin{array}{r}-0.7456 \\
(1.590)\end{array}$ \\
\hline Mang_Own & $\begin{array}{r}0.03218 \\
(0.020)\end{array}$ & $\begin{array}{l}0.0243 \\
(0.008)\end{array}$ & $\begin{array}{r}0.03912 \\
(0.015)\end{array}$ & $\begin{array}{l}0.0282 \\
(0.002)\end{array}$ & $\begin{array}{l}0.4621 \\
(0.017)\end{array}$ & $\begin{array}{l}0.1098 \\
(0.000)\end{array}$ \\
\hline firm_age & $\begin{array}{r}0.8254 * * * \\
(3.390)\end{array}$ & $\begin{array}{r}0.7382 * * * \\
(3.563)\end{array}$ & $\begin{array}{r}0.3268 * * * \\
(3.390)\end{array}$ & $\begin{array}{r}0.7332 * * * \\
(3.673)\end{array}$ & $\begin{array}{r}0.6943 * * * \\
(2.971)\end{array}$ & $\begin{array}{r}0.3795 * * * \\
(3.684)\end{array}$ \\
\hline Beta & $\begin{array}{r}-0.0304 \\
(-1.014)\end{array}$ & $\begin{array}{l}-0.0272 \\
(-0.066)\end{array}$ & $\begin{array}{l}-0.0308 \\
(-1.682)\end{array}$ & $\begin{array}{l}-0.0272 \\
(-0.077)\end{array}$ & $\begin{array}{r}-0.8944 \\
(1.014)\end{array}$ & $\begin{array}{r}-0.1654 \\
(0.256)\end{array}$ \\
\hline Firm_size & $\begin{array}{l}-0.0588 \\
(-0.003)\end{array}$ & $\begin{array}{l}0.0349 \\
(1.948)\end{array}$ & $\begin{array}{r}-0.0753 \\
(0.014)\end{array}$ & $\begin{array}{l}0.0389 \\
(0.045)\end{array}$ & $\begin{array}{c}-0.0958 \\
(0.000)\end{array}$ & $\begin{array}{l}0.1852 \\
(0.048)\end{array}$ \\
\hline ROE & $\begin{array}{r}0.16734 \\
(1.335)\end{array}$ & $\begin{array}{l}0.0753 \\
(0.092)\end{array}$ & $\begin{array}{r}0.17738 \\
(1.336)\end{array}$ & $\begin{array}{l}0.0763 \\
(0.014)\end{array}$ & $\begin{array}{r}0.14834 \\
(1.946)\end{array}$ & $\begin{array}{r}0.0363^{*} \\
(1.872)\end{array}$ \\
\hline Tax & $\begin{array}{l}-0.0142 \\
(-0.112)\end{array}$ & $\begin{array}{l}-0.0758 \\
(-0.343)\end{array}$ & $\begin{array}{l}-0.0182 \\
(-0.112)\end{array}$ & $\begin{array}{l}-0.0835 \\
(-0.243)\end{array}$ & $\begin{array}{l}0.0529 \\
(0.054)\end{array}$ & $\begin{array}{r}-0.0369 \\
(0.843)\end{array}$ \\
\hline Debt & $\begin{array}{l}0.0255 \\
(0.242)\end{array}$ & $\begin{array}{r}-0.00062 \\
(-1.109)\end{array}$ & $\begin{array}{l}0.0356 \\
(0.274)\end{array}$ & $\begin{array}{r}-0.0936^{* *} \\
(2.109)\end{array}$ & $\begin{array}{l}0.0283 \\
(0.008)\end{array}$ & $\begin{array}{r}-0.0852 \\
(0.193)\end{array}$ \\
\hline Industry & $\begin{array}{l}-0.0012 \\
(-0.894)\end{array}$ & $\begin{array}{l}0.0065 \\
(0.183)\end{array}$ & $\begin{array}{l}-0.0452 \\
(-0.398)\end{array}$ & $\begin{array}{r}0.1678^{* * * *} \\
(3.049)\end{array}$ & $\begin{array}{l}-0.0392 \\
(0.523)\end{array}$ & $\begin{array}{l}0.0274 \\
(0.236)\end{array}$ \\
\hline Region & $\begin{array}{r}0.1566 \\
(0.0003)\end{array}$ & $\begin{array}{r}0.6311 \\
(0.0451)\end{array}$ & -- & --- & --- & --- \\
\hline Constant & $\begin{array}{r}-1.1282 * * * \\
(-3.446) \\
\end{array}$ & $\begin{array}{l}-0.4782 \\
(-1.085) \\
\end{array}$ & $\begin{array}{r}-1.1232 * * * \\
(3.857) \\
\end{array}$ & $\begin{array}{r}-0.8731 \\
(1.054)\end{array}$ & $\begin{array}{r}-1.8649 * * * \\
(4.052)\end{array}$ & $\begin{array}{r}-0.5214 \\
(0.396)\end{array}$ \\
\hline R-squared & 0.3871 & 0.4205 & 0.3186 & 0.2965 & 0.3178 & 0.3271 \\
\hline Wald-Test & $194.25^{* * *}$ & $219.62 * * *$ & $182.19^{* * *}$ & $134.72 * * *$ & $164.71 * * *$ & $188.15^{* * *}$ \\
\hline Obs. & 1414 & 1861 & 804 & 950 & 610 & 911 \\
\hline
\end{tabular}


The variable duality is not significant. The impact on GCC firms' dividend yields is not significant for either firm group.

The table also shows that the interacted board size variables significantly and negatively affect dividend payouts and dividend decisions only for firms without CEO Duality. The results show that companies with larger boards and without CEO duality may mitigate the use of dividends as a signal for good performance during crisis periods, as the large board size itself can act as a credible signal to the market. The impact of Board size during the crisis is confirmed for firms in both regions, but the impact on GCC firms appears more significant.

Conc and Top5 appear to significantly and positively affect the dividend policy of firms with CEO duality during financial crises. This implies that in order to reduce agency costs during crisis periods, highly concentrated firms with larger capital portions held by the Top 5 can help the $\mathrm{CEO}$ who is also the chairman to exercise discretionary power on the management by increasing dividend payouts. The impact on GCC firms appears more significant than that on firms in the East Asian region.

The table shows that the results for the control variables appear globally in line with the previous results, except for ROC, which appears significantly negative in the case of firms with CEO duality and non-significant for firms without CEO duality.

Panel A shows that capital concentration during crises significantly affects dividend yields of both groups of GCC firms, but the impact is more significant for firms with CEO duality. Managerial ownership has a significant impact on dividend yield during crisis for East Asian firms functioning with CEO duality. In contrast, the impact of managerial ownership has no impact on GCC firms during the crisis.

Regarding GCC firms, the impact of Institutional ownership on dividend decisions appears significantly positive only for firms operating with CEO duality. Panel B also shows that Institutional ownership significantly affects both groups of East Asian firms. 


\section{Conclusion}

This study investigates the impact of corporate governance and ownership structure on dividend payout policy for a sample of 362 firms from East Asian and the GCC countries from 2003 to 2011. An interesting contribution of our study is testing whether the impact of corporate governance and ownership structure changes during crisis periods. Our results provide strong evidence of the significant role of corporate ownership structure and board characteristics in explaining the behavior of dividend policy mainly during crisis periods. We show that firms with a higher proportion of institutional shareholders pursue higher dividend payout ratios.

Focusing on the role of CEO duality when studying dividend policy, we show that in emerging countries, dividend policy in firms with CEO duality and firms without CEO duality do not depend on the same set of factors. Particularly, the ownership concentration and board independence variables appear to differently affect firms with CEO duality and without CEO duality.

Finally, the originality and the relevance of our research are found in the analysis of the most recent financial crisis. This study is of particular interest for business managers in their choice of strategies to be adopted in respect for dividend policy during crisis periods. The results show that during the most recent financial crisis, dividend decisions are inversely related to CEO Duality, Board Size and the frequency of board meetings.

\section{References}

Abreu, J. F. and Gulamhussen, M. (2013). "Dividend payouts: Evidence from U.S. bank holding companies in the context of the financial crisis". Journal of Corporate Finance. Vol 22, September, pp. 54-65.

Adjaoud, F. and Ben-Amar, W. (2010), “Corporate Governance and Dividend Policy: Shareholders' Protection or Expropriation?". Journal of Business Finance \& Accounting, Vol. 37, Issue 5-6, pp, 648-667.

Al-Kuwari, D. (2009), " Determinants of the Dividend Policy in Emerging Stock Exchanges: The Case of GCC Countries”. Global Economy and Finance Journal. Vol. 2 September, pp. 38-63.

Elsayed, K. (2007), “ Does CEO Duality Really Affect Corporate Performance?” Journal compilation Vol $15, \mathrm{~N}^{\circ} 6$, November, pp. 1203-1214.

Kuwari, D. (2009). "Determinants of the dividend policy in emerging stock exchanges: The case of GCC countries". Global Economy \& Finance Journal, Vol.2 N² 2, pp. 38-63.

Al-Malkawi, H. N. (2007). "Determinants of corporate dividend policy in Jordan: An application of the Tobit model". Journal of Economic and Administrative Sciences, Vol. 23, N², pp. 44-70. 
Amidu, M. and Abor J., (2006). "Determinants of Dividend payout ratios in Ghana". Journal of Risk Finance, Vol. 7, ’o2, pp. 136 - 145.

Baker, H. K., Veit, E. T., and Powell, G. E. (2001). "Factors Influencing Dividend Policy Decisions of NASDAQ Firms". The Financial Review, Vol 36. N³, pp. 19-38.

Baliga, B.R., Moyer, R.C. and Rao, R.S. (1996). "CEO duality and firm performance: what's the fuss?”, Strategic Management Journal, Vol. 17, N. 1, pp. 41-53.

Bistrova, J., Lace, N., and Kozlovskis, K. (2013). "Ownership Type Influence on Dividend Payments in CEE Countries”. Business: Theory and Practice Journal, Vol 1, N³, pp. 259-266.

Bokpin, A. (2011). "Ownership structure, corporate governance and dividend performance on the Ghana Stock Exchange." Journal of Applied Accounting Research, Vol. 12, № 1 pp. 61-73.

Borokhovich, K., Brunarski, K., Harman, Y., and Kehr, J. (2005). "Dividends, Corporate Monitors and Agency Costs". The Financial Review, Vol. 40, N 1, pp. 37-65.

Chen, Z., Cheung, Y.L., Stouraitis, A and Wong, A.W., (2005). "Ownership concentration, firm performance, and dividend policy in Hong Kong”, Pacific-Basin Finance Journal, Vol.13, pp. 431449.

Chen, L., C. Lin., and Yong-Cheol, K. (2011). "Financial Characteristics, Corporate Governance and the Propensity to Pay Cash Dividends of Chinese Listed Companies". International Business and Management, Vol. 3, $\mathrm{N}^{\circ} 1$, pp. 176-188.

Claessens, S. and Djankov, S. (1999). "Ownership concentration and corporate performance in the Czech Republic", Journal of Comparative Economics, Vol. 27,ํ3, pp. 498-513.

Claessens, S., Djankov S., Fan J. and Lang L., (1999), "Expropriation of Minority Shareholders: Evidence from East Asia", World Bank Policy Research Working Paper Series, Nº 2088.

Conger, J, Finegold, D and Lawler I, E (1998). “Appraising Boardroom Performance”, Harvard Business Review, Vol. 76, ํ1, pp. 136-148.

DeAngelo H., DeAngelo L. and Stulz R.M., (2006). "Dividend policy and the earned/contributed capital mix: a test of the life-cycle theory" Journal of Financial economics, Vol. 81, №2, pp. 227-254.

Demsetz, H. and Lehn, K. (1985). "The structure of corporate ownership: causes and consequences", Journal of Political Economy, Vol. 93, Nº6, pp. 1155-77.

Denis, DJ. (2008) "Why do firms pay dividends? International evidence on the determinants of dividend policy". Journal of Financial Economics, Vol. 89, N 1, pp. 62-82.

Eckbo, B.E., Verma, S. (1994). "Managerial share ownership, voting power, and cash dividend policy". Journal of Corporate Finance, Vol. 93, N${ }^{\circ}$, pp. 33- 62.

Faccio, M., Lang, L.H.P., and Young, L. (2001). Dividends and expropriation. American Economic Review, Vol. 91, №1, pp. 91,54-78.

Faleye, O. (2007). "Does one hat fit all? The case of corporate leadership structure". Journal of Management and Governance, Vol 11, N³, pp. 239-259.

Fama, E. and Harvey, B. (1968), "Dividend policy: an empirical analysis", Journal of the American Statistical Association, Vol 63, N³24, pp. 1132-1161.

Gugler, K. and Yurtoglu, B. (2003). "Corporate governance and dividend pay-out policy in Germany", European Economic Review, Vol. 47, N4, pp. 731-58.

Glen, J. D., Karmokolias, Y., Miller, R. R. \& Shah, S. (1995). "Dividend Policy and Behaviour in Emerging Markets: To Pay or Not to Pay". IFC Discussion Paper No. 26. 
Gregory, H.J. (2000). "The globalization of corporate governance", October 2000 issues of Global Counsel.

Harada, K. and Nguyen, P. (2005). "Dividend change context and signaling efficiency in Japan" PacificBasin Finance Journal, Vol. 13, ํ5, pp. 504-22.

Hauser, R. (2013). "Did dividend policy change during the financial crisis?". Managerial Finance. Vol. $39, \mathrm{~N}^{\circ} 6$, pp. 584-606.

Jensen, M. C. (1983). “Organization Theory and Methodology". Accounting Review, Vol. 58, ํ․ 1. pp 319-339.

Jensen, M. C. (1986). "Agency costs of free cash flow, corporate finance, and takeovers." American Economic Review, Vol. 76, ํㅜㄹ, pp. 323-329.

Jensen, M., (1993). The modern industrial revolution, exit, and the failure of internal control systems. Journal of Finance. Vol. 48, $\mathrm{N}^{\circ} 3$, pp. 831-880.

Jensen, M. C. and Meckling, W. H. (1976). "Theory of the Firm: Managerial Behavior, Agency Costs and Ownership Structure”. Journal of Financial Economics, Vol. 3, N4, pp. 305-360.

Johnson, S., Boone, P., Breach, A. and Friedman, E. (2000). "Corporate governance in the Asian Financial crisis”, Journal of Financial Economics. Vol. 58, N${ }^{\circ}$, pp. 141-186.

Khanna, V. and Zyla, R. (2010) "Corporate Governance Matters to Investors in Emerging Market Companies”. International Finance Corporation- Worl Bank Group, Survey says-2010.

Klein, A. (2002), "Audit committee, board of director characteristics, and earnings management", Journal of Accounting and Economics, Vol. 33 N. 3, pp. 375-400.

Kouki, M., and Guizani, M. (2009). "Pouvoir de vote des actionnaires et politique de dividende: Étude empirique sur les entreprises Tunisiennes cotées "'. Revue du financier, $\mathrm{N}^{\circ}, 178-179$.

Kowalewski, O. (2013). "Does Corporate Governance Determine Corporate Performance and Dividends During Financial Crisis: Evidence from Poland". http://fic.wharton.upenn.edu/fic/papers/12/12-14.pdf.

Laksmana, I. (2008) "Corporate board governance and voluntary disclosure of executive compensation practices”. Contemporary Accounting Research, Vol. $25 \mathrm{~N}^{\circ}$ 4, pp. 1147-1182.

La Porta, R., Florenico, L.D.S., Shleifer, A. and Vishny R.W. (2000). "Agency Problems and Dividend Policies Around the World”, Journal of Finance. Vol. 55, N 1, pp. 1-33.

Lipton, M et Lorsh, J. (1992). “A modest proposal for improved corporate governance”, Business Lawyer, Vol.48, $\mathrm{N}^{\circ} 1$, pp.59-77.

Maury, B. and Pajuste, A. (2002) "Controlling Shareholders, Agency Problems and Dividend Policy in Finland”, Journal of Business Economics. Vol. 51, ํ1, pp. 15-45.

Mehrani, S., Moradi M. and Eskandar H. (2011) "Ownership structure and dividend policy: Evidence from Iran”, African Journal of Business Management. Vol. 5, N 17, pp. 7516-7525,

Michel, A. J. and Shaked I. (1986). "Country And Industry Influence On Dividend Policy: Evidence From Japan And The U.S.A". Journal of Business Finance and Accounting. Vol. 13, N³, pp. 365382.

Mitton, T. (2004). "Corporate governance and dividend policy in emerging markets", Emerging Markets Review, Vol. 5, N4, pp. 409-26. 
Omneya, A., El-Masry, A. and Elsegini, S. (2008) "Board composition, ownership structure and dividend policies in an emerging market, Further evidence from CASE 50". Managerial Finance. Vol. $34 \mathrm{~N}^{\circ}$. 12, pp. 953-964.

Pruitt, S. and Gitman,. J. (1991). "The Interactions between the Investment, Financing, and Dividend Decisions of Major U.S. Firms". Financial Review. Vol. 26, N 3, pp. 409-430.

Redding, L.(1997). "Firm Size and Dividend Payouts". Journal of Financial Intermediation. Vol. 6, N³, pp. 224-248.

Rozeff, M. S. (1982). "Growth, Beta and Agency Costs as Determinants of dividend." The Journal of Financial Research, Vol.5, N³, pp. 249-259.

Sawicki J. (2009). "Corporate Governance and Dividend Policy in Southeast Asia Pre- and Post-Crisis." European Journal of Finance., Vol. 15, $\mathrm{N}^{\circ}$ 2, pp. 211-230.

Schellenger, M.H., Wood, D.D. and Tashakori, A. (1989). "Board of Director Composition, Shareholder Wealth, and Dividend Policy". Journal of Management, Vol.15, №3, pp. 457-467.

Shleifer, A. and Vishny, R. (1986). "Large Shareholders and Corporate Control", Journal of Political Economy, Vol 94. $\mathrm{N}^{\circ} 3$, pp. 461-488.

Shleifer, A. and Vishny, W. (1997). "A Survey of Corporate Governance". The Journal of Finance, Vol $52, \mathrm{~N}^{\circ} 2$, pp. 737-783.

Short, H., Zhang H, and Keasey, K. (2002). "The link between dividend policy and institutional ownership”. Journal of Corporate Finance, Vol. 8, №2, pp. 105-122.

Stacescu B. (2006) "Dividend Policy in Switzerland", Financial Markets and Portfolio Management, Vol. $20, \mathrm{~N}^{\circ} 2$, pp. 2006.

Waud, R (1966). "Small sample bias due to misspecification in the partial adjustment and adapted expectations models". Journal of American Statatistic Association. Vol. 63, N³, pp. 134- 145.

Wellalage, N. and Locke, S. (2011). "Does CEO Duality is Really Matter? Evidence from an Emerging Market". Corporate Ownership and Control, Vol. 8, No. 4, pp.112-122.

Wen, Y. and Jia, J. (2010). "Institutional ownership, managerial ownership and dividend policy in bank holding companies", International Review of Accounting, Banking, and Finance, Vol. 2, Nº1, pp. 821.

Zeckhauser, R. J., and Pound, J. (1990), “Are large shareholders effective monitors? An investigation of share ownership and corporate performance". In: R. G. Hubbard (ed.), Asymmetric information, corporate finance, and investment, Chicago: University of Chicago Press. 